University of Louisville

ThinkIR: The University of Louisville's Institutional Repository

$12-2014$

\title{
Job satisfaction of professional staff and administrators within the associated colleges of the south : a study of Herzberg's duality theory of motivation in higher education.
}

J. Patrick Noltemeyer 1979-

University of Louisville

Follow this and additional works at: https://ir.library.louisville.edu/etd

Part of the Higher Education Administration Commons

\section{Recommended Citation}

Noltemeyer, J. Patrick 1979-, "Job satisfaction of professional staff and administrators within the associated colleges of the south : a study of Herzberg's duality theory of motivation in higher education." (2014). Electronic Theses and Dissertations. Paper 1748.

https://doi.org/10.18297/etd/1748

This Doctoral Dissertation is brought to you for free and open access by ThinkIR: The University of Louisville's Institutional Repository. It has been accepted for inclusion in Electronic Theses and Dissertations by an authorized administrator of ThinkIR: The University of Louisville's Institutional Repository. This title appears here courtesy of the author, who has retained all other copyrights. For more information, please contact thinkir@louisville.edu. 


\title{
JOB SATISFACTION OF PROFESSIONAL STAFF AND ADMINISTRATORS WITHIN THE ASSOCIATED COLLEGES OF THE SOUTH: \\ A STUDY OF HERZBERG'S DUALITY THEORY OF MOTIVATION IN HIGHER EDUCATION
}

\author{
By \\ J. Patrick Noltemeyer \\ B.S., Centre College, 2001 \\ M.S., University of Kentucky, 2004

\begin{abstract}
A Dissertation
Submitted to the Faculty of the

College of Education and Human Development of the University of Louisville in Partial Fulfillment of the Requirements

for the Degree of
\end{abstract}

Doctor of Philosophy

Department of Educational \& Counseling Psychology,

Counseling, and College Student Personnel

University of Louisville

Louisville, Kentucky

December 2014 



\section{JOB SATISFACTION OF PROFESSIONAL STAFF AND ADMINISTRATORS WITHIN THE ASSOCIATED COLLEGES OF THE SOUTH:}

\section{A STUDY OF HERZBERG'S DUALITY THEORY OF MOTIVATION IN HIGHER EDUCATION}

\section{By}

J. Patrick Noltemeyer

B.S., Centre College, 2001

M.S., University of Kentucky, 2004

A Dissertation Approved on

November 20, 2014

by the following Dissertation Committee

Dr. Amy Hirschy, Dissertation Chair

Dr. Jake Gross

Dr. Bridgette Pregliasco

Dr. Brad Shuck 


\section{DEDICATION}

I dedicate this dissertation to my wife, Megan Noltemeyer, my best friend and source of constant support who has taken each step of this journey with me. Your belief in and love for me makes me feel all things are possible. 


\section{ACKNOWLEDGEMENTS}

Many thanks go to Dr. Amy Hirschy for her consistent support and guidance in the preparation and implementation of this study as well as the composition of this document, which describes the results. I am grateful for the time you spent reading numerous drafts of this dissertation and for your constant encouragement.

I am also thankful to the members of my dissertation committee, Dr. Jake Gross, Dr. Bridgette Pregliasco, and Dr. Bradley Shuck, for their careful and thoughtful review of this study in its proposal stage and their insights regarding the best way to present the results. Your expertise, guidance, and support were critical to the completion of this work.

The faculty members of the ECPY department of the University of Louisville prepared me to complete this project with challenging classes, engaging discussions, and creative opportunities to learn and excel. I am grateful for their efforts.

This research would not have been possible without the support of institutional leaders within the Associated Colleges of the South, including its immediate past president, Dr. Wayne Anderson. I am grateful for your support of this project.

Finally, I must acknowledge and thank my colleagues and supervisors at Centre College who allowed me to have a flexible schedule to attend classes and conduct research, and who listened to numerous iterations of my theories regarding the results of this study and the job satisfaction levels of higher education employees in general. 


\begin{abstract}
JOB SATISFACTION OF PROFESSIONAL STAFF AND ADMINISTRATORS WITHIN THE ASSOCIATED COLLEGES OF THE SOUTH: A STUDY OF HERZBERG'S DUALITY THEORY OF MOTIVATION IN HIGHER EDUCATION
\end{abstract}

\title{
J. Patrick Noltemeyer
}

November 20, 2014

This study examined the ability of four groups of factors to predict the job satisfaction levels of fulltime, exempt, professional staff at four institutions of higher education within the Associated Colleges of the South consortium. Based on a similar study of professionals in higher education conducted by Smerek and Peterson (2007), this study used hierarchical multiple regression to determine the amount of variability explained by each group of factors according to the conceptual model. The conceptual model for this study, as well as the study by Smerek and Peterson, was based on the theory of Frederick Herzberg (1959), an industrial organizational psychologist who described job satisfaction and job dissatisfaction as disparate variables. Professional staff members received an anonymous web-based survey that measured levels of job satisfaction and collected information on personal and work characteristics. The survey also collected employee responses to two categories of variables - motivator factors and hygiene factors - identified by Herzberg as components of job satisfaction and job dissatisfaction. Results of this survey suggested that four variables accounted for statistically significant portions of job satisfaction - responsibility, work itself, effective 
supervisor, and recognition. One variable had a negative statistically significant relationship with job satisfaction - core values. The combination of statistically significant factors supports the acceptance of one of this study's hypotheses, that the Herzberg duality theory of job satisfaction is not supported in a higher education context. The job satisfaction levels of fulltime professional exempt employees in higher education matter; not only have higher levels of job satisfaction been connected to higher levels of efficiency and effectiveness, increases in job satisfaction have been linked to more positive work environments, improved campus culture, higher employee retention and ultimately with institutions identified as "Great Places to Work For." The importance of job satisfaction in the higher education environment and was the impetus for this examination of Herzberg's duality theory of motivation. The results of this study are encouraging for leaders in higher education as they suggest opportunities for increasing job satisfaction that may be of relatively low cost while creating high impact. 


\section{TABLE OF CONTENTS}

\section{PAGE}

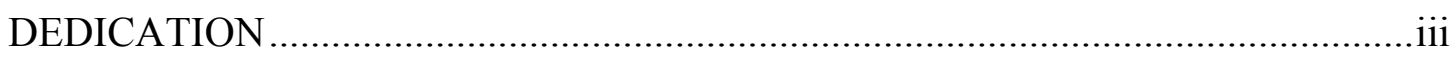

ACKNOWLEDGEMENTS ................................................................................

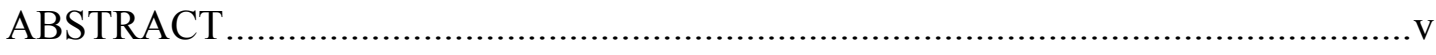

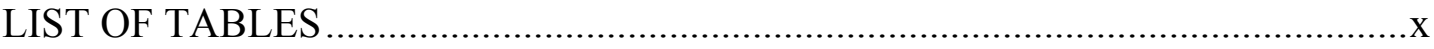

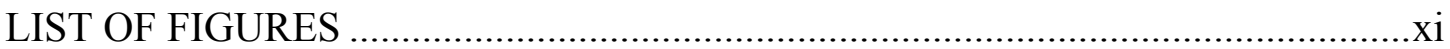

\section{CHAPTERS}

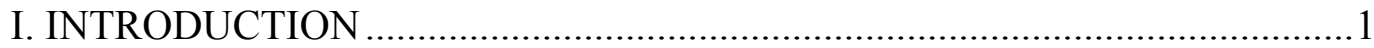

Challenges for Institutions of Higher Education ..................................

Associated Colleges of the South ..........................................................6

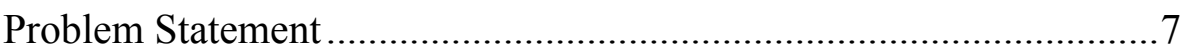

Significance of the Study ……………..............................................

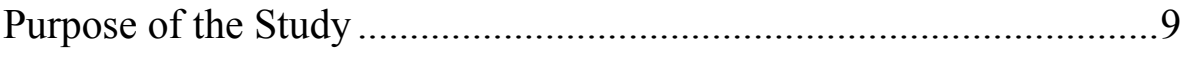

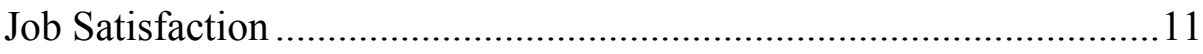

Conceptual Model ...............................................................................11

Research Questions and Hypotheses ...............................................13

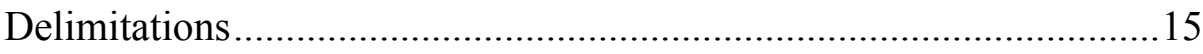

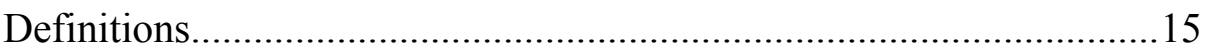


II. REVIEW OF LITERATURE............................................................. 16

Job Satisfaction and Job Dissatisfaction .......................................... 17

Work Climate in Higher Education ................................................19

Extrinsic and Intrinsic Motivation ...................................................22

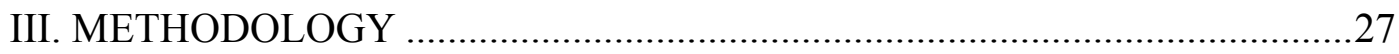

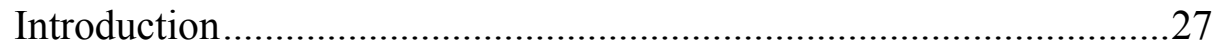

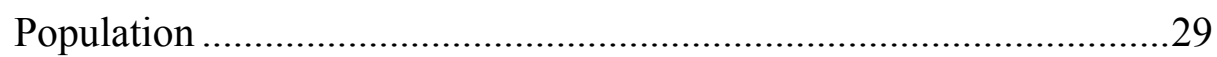

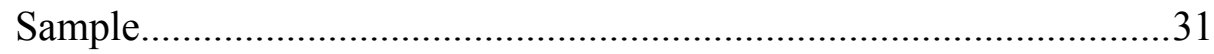

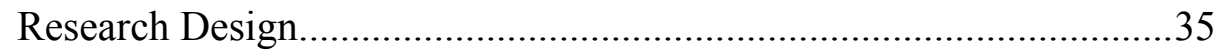

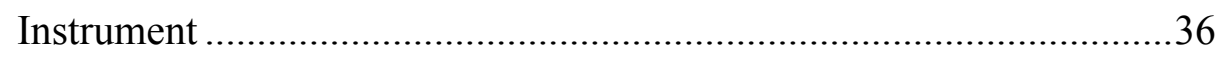

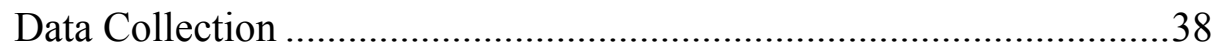

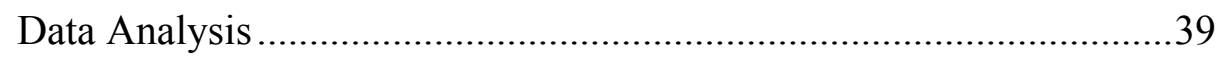

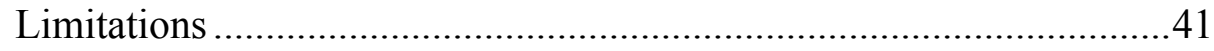

IV. RESULTS OF THE STUDY .............................................................43

Population and Data Collection ...................................................43

Data Analysis ................................................................... 44

Descriptive Statistics............................................................ 45

Reliability Analysis........................................................... 46

Inferential Statistics Analysis ...............................................47

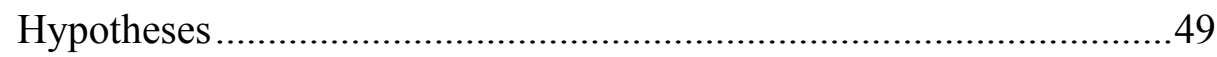


V. DISCUSSION, IMPLICATIONS, AND CONCLUSIONS ..........................51

Descriptive Statistics................................................................52

Reliability Analysis..............................................................53

Inferential Statistics Analysis ....................................................54

Implications for Practice ......................................................6 61

Recommendations for Future Research ........................................62

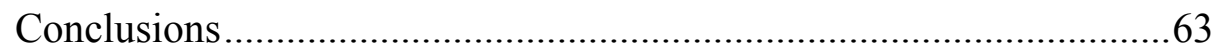

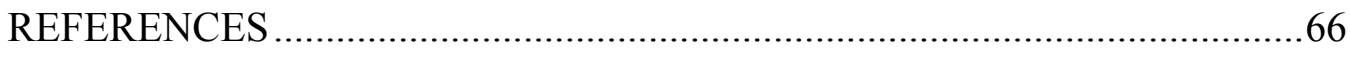

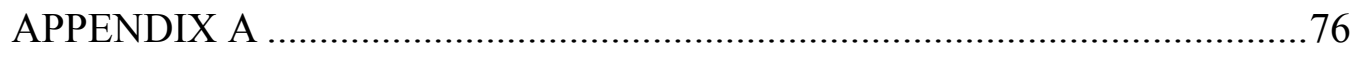

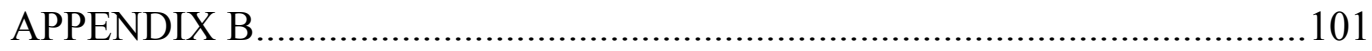

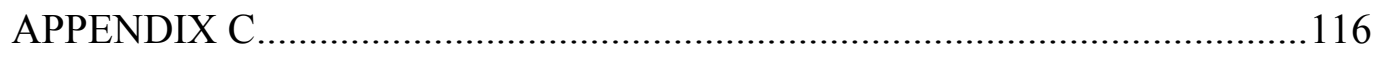

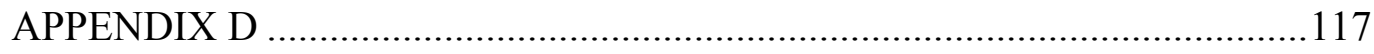

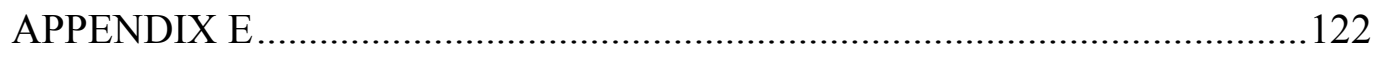

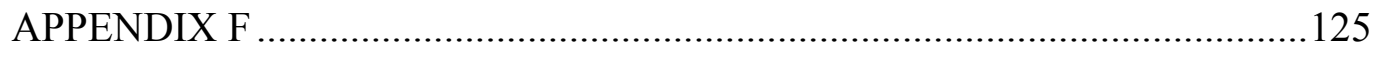

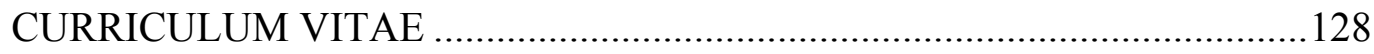




\section{LIST OF TABLES}

TABLE

PAGE

1. Number of employees at ACS institutions.............................................................3

2. Job satisfaction scores...................................................................................44

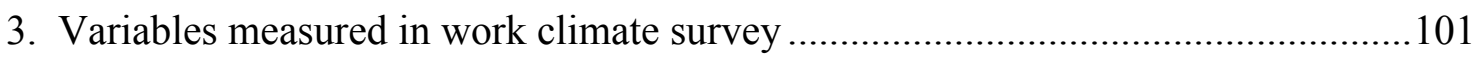

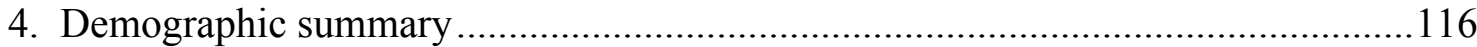

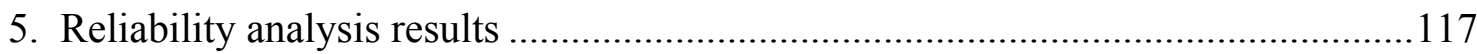

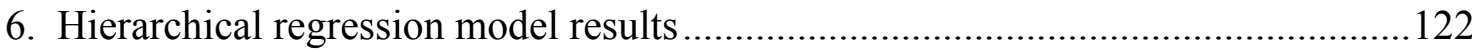

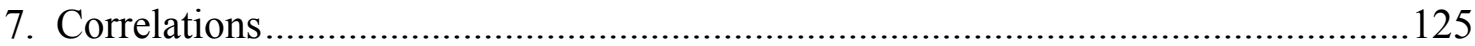




\section{LIST OF FIGURES}

\section{FIGURE}

1. Fulltime professional staff in higher education .......................................................

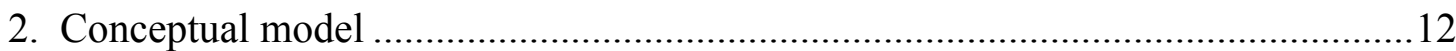

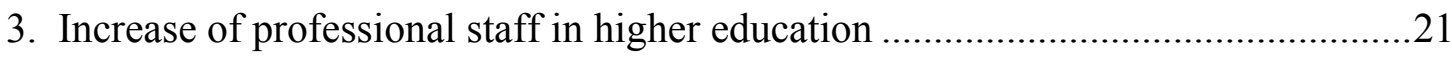




\section{CHAPTER I}

\section{INTRODUCTION}

\section{Challenges for Institutions of Higher Education}

The individuals charged with the leadership of institutions of higher education all seek ways to succeed and provide educational opportunities in new and different ways to help to differentiate their institutions from their peers (Agresto, 2011). Facing strong competition for quality students, these educational leaders are challenged to find new ways to attract attention, market the quality of their educational experience, and be certain that student return on investment is high. In addition to these challenges, leaders in higher education face hurdles associated with decreased state and federal funding (McLendon, Hearn, \& Mokher, 2009; Tandberg, 2010) and increased accountability from accrediting agencies, students and families, and the federal government (Cowan, 2013). To continue to fulfill their missions, institutions must continue to provide the opportunities and challenges necessary for students to transform while often having fewer funds with which to work. As a result, institutional leaders are pushed to become more nimble - making more effective and efficient use of the resources at their disposal, financial and otherwise. The assessment process has provided a tool for leaders to use in identifying areas of strength and opportunity, and has helped institutions to identify those elements of their culture that contribute most greatly to the transformative educational experience and those which are more superfluous, or at least need to be improved. One 
area research and assessment have been used with high frequency includes people - the faculty, staff, and administrators who facilitate the educational experience.

A source of high investment and high impact at institutions of higher education is personnel - a group that totaled approximately 4 million individuals in the fall of 2012 (NCES). Consuming large percentages of an institution's operating budget with salaries and benefits, administrators, staff, and faculty embody the values and traditions of their college or university and maintain the educational infrastructure that helps develop students. While the number of faculty employed by institutions of higher education has grown modestly in the last twenty years, the number of staff and administrators at these institutions increased exponentially. Smith, Tovar, and Garcia (2012) identified a 33\% growth in the number of faculty employed in higher education from 1993 to 2009, though the growth of faculty has slowed considerably since (College Board, 2012). Figure 1 depicts the rapid growth of fulltime non-faculty professional staff in higher education since 1976 - an increase of $369 \%$ in that timespan - compared to a dramatically slower rate of expansion $(23 \%)$ of fulltime tenured and tenure-track faculty (Curtis \& Thornton, 2014). The growth of professional staff increased from $9 \%$ of the total number of higher education employees in 1976 to 25\% of employees in 2011 (College Board, 2012). The increase in the number of administrators and staff at institutions of higher education places significant demands on institutional budgets, pushing institutional leaders to find ways to make the most of their investment - to get the most from their people. Research efforts address this issue, but the balance of studies tilt significantly toward the faculty (Johnsrud, 2002; Johnsrud \& Rosser, 1999). 


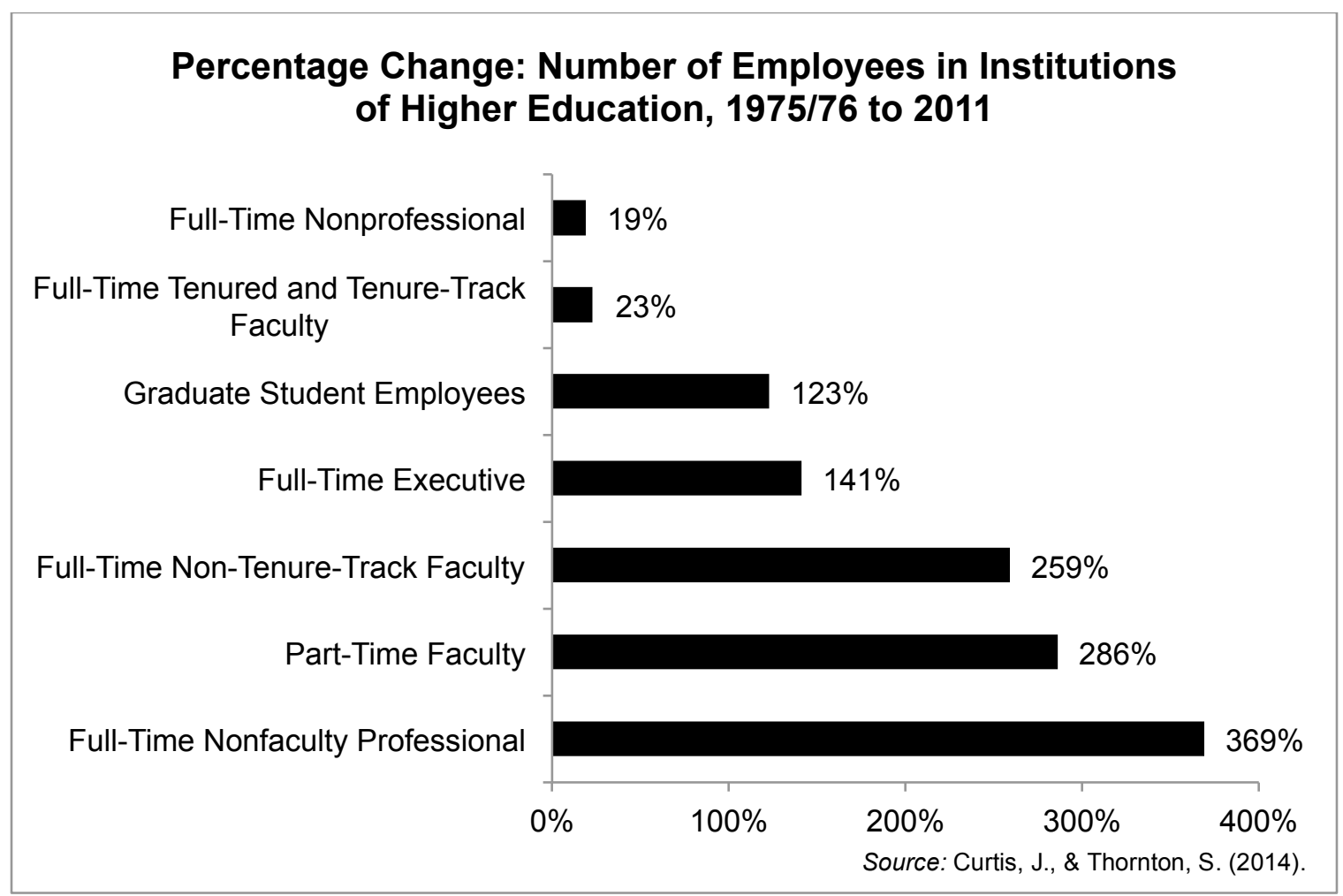

Figure 1. Growth of fulltime professional staff in higher education

A great deal of research has been conducted on faculty groups in higher education settings, including examinations of performance, workload, and the impact of the growing use of adjuncts on the profession (Dennison, 2011; Liftig, 2014; Waltman, Bergom, Hollenshead, \& Miller, 2012). Researchers have also studied faculty intentions to stay or leave a particular institution, or the field of higher education in general, related closely to sentiments of job satisfaction and job dissatisfaction (Marston \& Brunetti, 2009; Ryan, Healy, \& Sullivan, 2012). However, similar studies that focus on staff and administrators at institutions of higher education are in shorter supply. Those that have investigated both staff and faculty motivation have discovered different factors motivate the two groups. Some studies have demonstrated that faculty members are more motivated by intrinsic factors (i.e. satisfaction with the academic components of their positions) while staff reported being more motivated by extrinsic factors (i.e. salary 
satisfaction and relationships with university management) (Fuller, Hester, Barnett, Frey, \& Relyea, 2006; Kusku, 2003). The differences in what drives these two groups of individuals, in addition to the variance in their list of responsibilities in the workplace suggest that they should be studied as independent populations.

While studies have examined the growth of administrative and staff roles at institutions of higher education (Desrochers \& Kirshstein, 2014; Curtis \& Thornton, 2014), and others have explained the important influence people in these positions have on the student learning experience (Rosser, 2000; Rosser, 2004), a gap in the research exists when it comes to understanding the factors related to staff job satisfaction. Given the importance of their work and the relative investment of institutional financial resources in these individuals, it is notable that the number of studies on staff is much lower than that of research on faculty or faculty motivation (Johnsrud, 2002). While the direct impact of job satisfaction may be unclear, several studies have demonstrated the importance of employee satisfaction in higher education and the impact of happiness on productivity, effectiveness, and efficiency (Robbins, 1998; Brown \& Sargeant, 2007). Some research has found that unhappy workers results in higher levels of turnover and an increased difficulty in filling vacant positions (Florenthal \& Tolstikov-Mast, 2012). Research has shown that the work environment "influences (a) the amount of work employees complete, (b) attitudes toward the work place, [and] (c) employees' sense of community" (Biemiller, 2008; Florenthal, Tolstikov-Mast, \& Yilmazsoy, 2009). More work is needed to identify the factors that best predict job satisfaction and overall employee performance in order to capture the opportunity to improve the college experience. Surveys such as those conducted by the Chronicle of Higher Education in 
cooperation with consulting agency ModernThink, LLC have provided general information on whether or not employees are satisfied with the perceived work environment at institutions of higher education. This study takes that research one step forward by focusing on a smaller, more specific set of factors that contribute to job satisfaction, and narrowing the population sampled to exempt, fulltime staff employees employed within a group of institutions located in the southern region of the United States. The purpose of this study is to test the validity of Herzberg's (1959) theory in the context of institutions of higher education and provide information that will help institutional administrators better understand the factors involved in creating a positive work environment - and therefore a better educational environment - for their nonteaching, fulltime exempt employees.

One of the few existing studies on the job satisfaction of staff employees in higher education was conducted by Smerek and Peterson (2007). Their study examined the relevance of Herzberg's (1959) duality theory of motivation in a higher education setting using a group of more than 2,500 business employees at a large research university. Results demonstrated mixed support for Herzberg's theory that articulates specific factors that affect job satisfaction and job dissatisfaction independently in the work environment. Personal and work unit characteristics did not predict a significant portion of the variance in job satisfaction in the Smerek and Peterson (2007) study, and multiple factors from Herzberg's categories of motivator and hygiene factors explained a portion of the variance in job satisfaction. The motivators age, work itself, responsibility, and clarity of mission were all statistically significant predictors of job satisfaction, as were the hygiene factors effective senior management, effective supervisor, and satisfaction with salary. 
While the work of Smerek and Peterson (2007) identified several factors that were statistically significant, their study needs to be extended in a different setting to verify their results. This study will extend this research with a different cohort of employees to determine if those factors accounting for the most variance in job satisfaction in previous research are significant with a different population. This study will extend research in this area, focusing on professional, exempt, non-teaching staff employed fulltime at colleges and universities within the Associated Colleges of the South (ACS).

\section{Associated Colleges of the South}

The cohort of institutions selected for study comprises the Associated Colleges of the South (ACS), a strong regional consortium of private liberal arts colleges and universities that spans twelve states. ACS schools provide outstanding educational experiences for their students and have been recognized nationally year after year for the quality of their programs. In 2012, seven of the sixteen schools were ranked by Forbes magazine in the top 100 of all institutions of higher education in the United States, including the overall "Best Southern College," Washington and Lee University. U.S. News and World Report (2012) ranked eleven of the sixteen colleges in their top 100 liberal arts institutions in the nation in the same timeframe. Additionally, Washington Monthly ranked twelve of the sixteen schools in its top-100 list of national liberal arts institutions in fall 2012. Most important for this study, one quarter of the ACS schools were recognized by the Chronicle of Higher Education as "Great Places to Work For" in 2012, with Furman University appearing on this list for the fourth consecutive year. This recognition, specifically, would suggest that at least $25 \%$ of the institutions within the ACS would have employees who demonstrate high levels of job satisfaction. By 
studying the job satisfaction levels of employees at ACS institutions, this research may help to explain job satisfaction levels of employees at similar types of institutions liberal arts colleges and universities across the United States. This research may reveal a relationship between high quality educational experiences and high levels of job satisfaction among employees and make a stronger case for institutional leadership to make the satisfaction levels of their employees a priority. Based on the broader body of evidence, it is clear this group of institutions have the resources, people, and structures in place to provide a top-notch educational experience for undergraduates.

\section{Problem Statement}

While the institutions within the ACS have been recognized for their excellence, they face the challenge of redefining themselves in a shifting higher education landscape. Escalating tuition costs coupled with declining investment returns, a slow recovery from a global recession, and higher expectations from a generation of Millennial students (and their parents) are independent challenges exacerbated by their interrelated nature (Miller \& Slocombe, 2012). Resources from both federal and state sources have decreased significantly as institutions of higher education face competition for limited funding from healthcare, the prison system, and K-12 education systems (McLendon, Hearn, \& Mokher, 2009; Tandberg, 2010). Though the total amount of resources has increased, the amount of the total cost of higher education covered by state and federal student financial aid has decreased since 2001 while the need for graduates with bachelor's degrees and more specialized training has grown. Institutions of higher education are increasingly challenged to prove the worth of their educational experiences - and the value of the 
public's investment - as more often higher education is viewed as both a public and private good (Kallison \& Cohen, 2010).

Institutions of higher education are challenged to identify ways to improve efficiency, and make hard choices between competing goods - while producing highly educated, trained, and prepared graduates who are ready for the demands of the workplace (Kallison \& Cohen, 2010). Given that the largest categorical expenditure for most institutions of higher education is human resources - salaries and benefits - it makes sense to critically assess performance in this area (Johnsrud, 2002). Those individuals categorized as administrators and exempt professional employees may be some of the largest campus employee constituencies, engaging with students, parents, faculty, and community members in a variety of ways and representing the character, quality, and care of the institution. Their attitude toward the organization can influence the opinions of the wide variety of individuals with whom they work (Rosser, 2004).

Unfortunately for those in positions of institutional leadership, no clear formulas have been established to help regularly and positively contribute to the job satisfaction levels of staff in their employ. According to Johnsrud and Rosser (1999), "much of what is known about the factors contributing to the satisfaction of midlevel administrators is idiosyncratic and noncumulative," (p. 122). Rosser (2004) also suggests that despite the expansive growth of professional staff positions in institutions of higher education, they are still lack visibility and understanding in the academy, and more research is needed to explain the role of job satisfaction and morale in their performance and persistence.

Administrators and faculty leaders at institutions of higher education are challenged to identify those factors critical to the student educational experience and 
make the provision of those experiences both efficient and effective, including finding ways to maximize employee performance in the educational environment. A critical element to high employee performance may be job satisfaction which this study investigates.

Significance of the Study

This research contributes to the growing body of evidence regarding the importance of various factors that contribute to the job satisfaction of fulltime professional staff employees in higher education. This study will test the validity of Herzberg's theory in the context of institutions of higher education and provide information that will help institutional administrators better understand the factors involved in creating a positive work environment for their non-teaching, fulltime exempt employees.

\section{Purpose of the Study}

While they do not teach in formal classroom settings, the work of professional, fulltime administrators contributes in both direct and indirect ways to the overall student experience at each institution of higher education. These administrators play a vital role in creating a welcoming, supportive, and developmental campus climate through their work and interactions with faculty, students, and other staff members on campus (Scott, 1978). "Considered to be on the 'firing line' or in 'linking-pin' positions," these individuals work with outside vendors and organizations to arrange speakers and activities in which students participate, work with donors to raise funding to support student scholarships and programming budgets, work with students and community partners to facilitate service experiences, and often sit down for one-on-one direct 
conversations with individual students about their success (Johnsrud \& Rosser, 1999, p. 122). While some of this work is in direct contact with students, much of these efforts are behind the scenes, contributing to a positive educational experience without notoriety.

Research has demonstrated that satisfied employees - both faculty and staff create a positive working environment (Johnsrud, 2002). Employees laboring in a positive work environment are more productive and create a campus culture that is inviting and appealing to prospective students (Szekeres, 2006). Because of the interactions between students and staff in a variety of capacities each day, as well as the work they do with members of the outside community, the efforts made by staff outside the classroom can play a significant role in the image of the college both internally and externally. While it is the responsibility of the student to engage in their academic work and other aspects of the campus experience, engagement is a two-way street, meaning that faculty and staff bear some responsibility for creating an environment in which students can excel (Kuh, 2009). The work of the staff can have a major impact on the student experience and the campus culture as a whole, with a healthy organizational culture impacting student retention in a positive way (Johnsrud \& Rosser, 1999; Del Rey \& Romero, 2004; Van Vaught, 2008; Florenthal \& Tolstikov-Mast, 2012).This study investigates the work life of fulltime exempt professional staff (salaried, non-teaching personnel) at private liberal arts institutions of higher education in the southern region of the United States. While the direct impact of job satisfaction may be unclear, several studies have demonstrated the importance of employee satisfaction in higher education and the impact of happiness on productivity, effectiveness, and efficiency (Robbins, 1998; Brown \& Sargeant, 2007). More work is needed to identify the factors that best 
predict job satisfaction and overall employee performance. Surveys such as those conducted by the Chronicle of Higher Education in cooperation with consulting agency ModernThink, LLC have provided general information on whether or not employees are satisfied with the perceived work environment at institutions of higher education. This study takes that research one step forward by focusing on a smaller, more specific set of factors that contribute to job satisfaction, and narrowing the population sampled to exempt, fulltime staff employees employed within a group of institutions located in the southern region of the United States.

\section{Job Satisfaction}

Before articulating a theoretical explanation of the constructs that comprise job satisfaction, it is important to establish a definition for this concept. Early studies of job satisfaction describe the concept as the intersection between the amount of value an individual places on the work he or she is doing, and the amount of enjoyment he or she obtains from completing it (Locke, 1968). Locke continues to describe job satisfaction as a composite of feelings regarding the various aspects of a person's work, which supports the examination of factors that contribute to an overall feeling of job satisfaction as explored in this study (1968).

\section{Conceptual Model}

This study builds upon the work of Ryan E. Smerek and Marvin Peterson (2007) who studied a large number $(2,500+)$ of business operations employees at a large public research university. The authors point out that there is much room for continued research in the area of job satisfaction within colleges and universities, and that no consensus has yet been reached as to the factors that most affect job satisfaction in higher education. 
Several studies have measured the job satisfaction levels within administrators and staff in higher education, but very few have focused on the factors that contribute to those levels (Volkwein \& Zhou, 2003).

Job satisfaction serves as the dependent variable in this study. The independent variables in this study are divided into two categories, motivators and hygiene factors. Each of these independent variables, as well as the dependent variable, is affected by personal and work characteristics. Figure 2 displays a visual representation of this conceptual model. According to Herzberg, much of the variance in job satisfaction is accounted for by motivators.

Influences on the Work
Environment

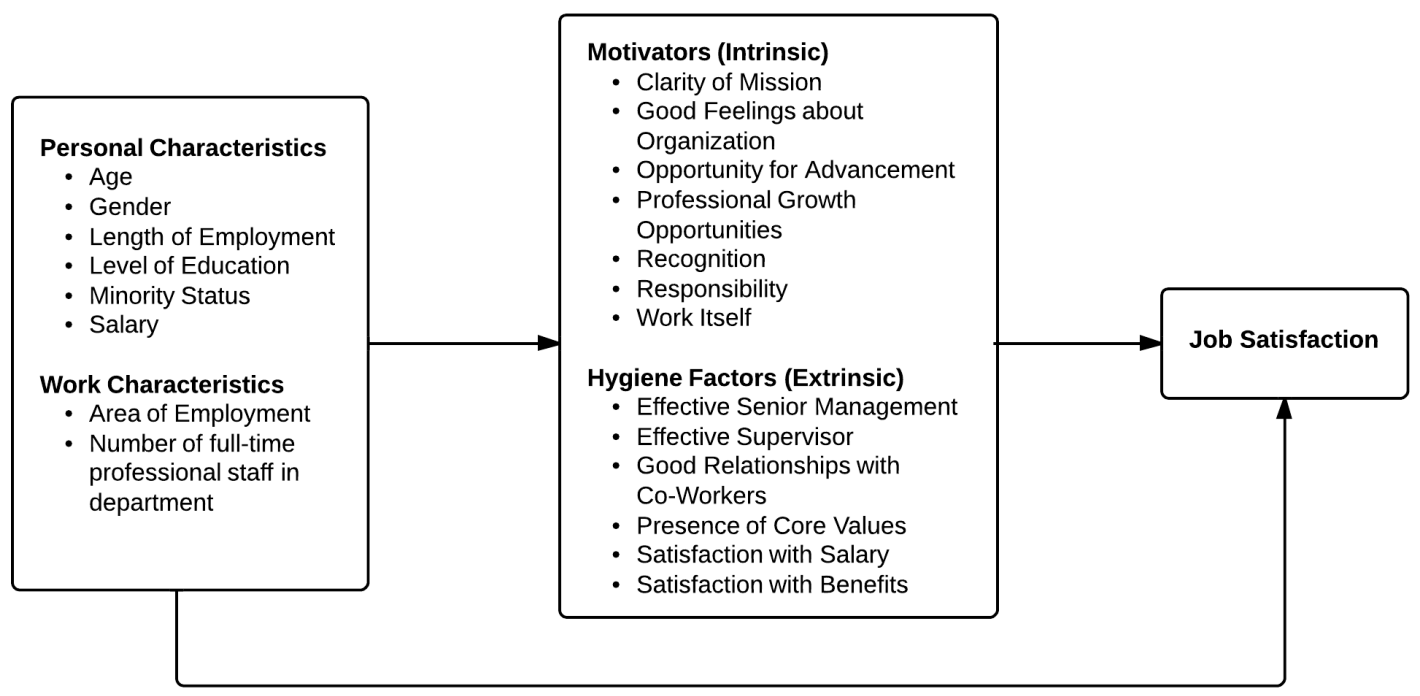

Figure 2. Conceptual model 


\section{Research Questions and Hypotheses}

This research investigates questions similar to those addressed by Smerek and Peterson (2007), but with a different population - fulltime, salaried, non-teaching professional employees at liberal arts institutions within the ACS. These researchers identified several motivators (age, work itself, opportunity for advancement, responsibility, and clarity of mission) and hygiene factors (effective senior management, effective supervisor, satisfaction with salary) that predicted job satisfaction levels. These statistically significant results suggest that Herzberg's theory is not supported in a higher education context - results that informed the hypotheses created for this study.

This research extends the work of Smerek and Peterson (2007) and continues to examine the validity of Herzberg's (1959) duality theory of motivation in a higher education context. As such, the research questions focus on the two groups of elements that Herzberg identified - motivators and hygiene factors. All factors from each of Herzberg's factor categories were included. Herzberg's (1959) theory and the results from the Smerek and Peterson (2007) study have influenced the creation of this study's hypotheses. The research questions are presented below with relevant hypotheses.

1. Do the factors within the perceived work environment predict job satisfaction?

$\mathrm{H}_{1}$ : There is a significant predictive relationship between the motivators (intrinsic factors) (clarity of mission, good feelings about organization, opportunity for advancement, professional growth opportunities, recognition, responsibility, work itself) and the dependent variable, job satisfaction. 
2. Is Herzberg's duality theory of motivators and hygiene factors supported in this higher education context?

$\mathrm{H}_{2}$ : Herzberg's duality theory of motivators and hygiene factors will be not be supported in this context because a significant predictive relationship will be found between hygiene factors and the dependent variable, job satisfaction.

This work will test the validity of Herzberg's theory in a group of private institutions of higher education and will help institutional administrators better understand the factors involved in creating a positive work environment for members of their staff. As in the study by Smerek and Peterson (2007), the dependent variable job satisfaction is comprised of "(1) whether a job meets expectations, (2) is close to an ideal job, and (3) how satisfied a person is with their job" (p. 234). While a significant amount of research has been conducted regarding job satisfaction, there is still some debate about which factors contribute most significantly to both job satisfaction in the workplace, or in this case, on campus (Brown \& Sargeant, 2007). By examining the factors contributing to the levels of job satisfaction of non-teaching, salaried, fulltime professional employees at institutions of higher education, this study will contribute to the understanding of the significance of the work environment at institutions of higher education.

Limiting the institutions considered to private colleges and universities within the ACS expands the work of Smerek and Peterson (2007) by exploring the effects of the work environment within a different population. Though the overall population sampled in this study will come from multiple institutions, these schools are similar in their purpose, size, and approach to education. Effects of the various factors measured in this 
study will be examined in aggregate as well as by institution to determine any institutional differences.

\section{Delimitations}

This study is limited to the fulltime professional exempt non-faculty employees at institutions of higher education in the Associated Colleges of the South consortium. The study is further limited by the number of individuals who agree to voluntarily participate in the study and to those who are currently employed at these institutions.

\section{Definitions}

Job Satisfaction: The intersection between the amount of value an individual places on the work he or she is doing, and the amount of enjoyment he or she obtains from completing it. Job satisfaction is a composite of feelings regarding the various aspects of a person's work (Locke, 1968).

Administration: Individuals categorized as members of the administration include deans, provosts, and individuals at the director level who have supervisory responsibility, are paid a salary rather than an hourly rate, and are senior staff members at an institution of higher education. These individuals are often not in direct service roles and may have responsibility for the institution as a whole.

Exempt professional staff: Individuals with titles such as analyst, advisor, counselor, and specialist who may or may not have supervisory responsibilities, are paid a salary rather than an hourly rate, who are not senior members of the staff of an institution of higher education. These individuals are often direct service providers and report to members of the administration. 


\section{CHAPTER II}

\section{REVIEW OF LITERATURE}

Institutions of higher education provide educational experiences for undergraduate and graduate students every day of the year, on almost every continent across the world. Arguably, the professors who teach students in the formal classroom setting - the faculty - are the foundation upon which this education rests, as their expertise, wisdom, and experience are passed on to their students through lectures, group activities, projects, lab work, and more. Supporting these efforts, and the lives of the student body while not in the classroom, are men and women who construct financial aid packages, recruit new students, engage alumni, provide developmental student leadership experiences, counsel students through happiness and grief, and educate students through a variety of co-curricular and extra-curricular avenues. These non-academic employees play a vital role in educating students and creating a positive campus environment, even though much of that education happens outside the classroom. Staff members at institutions of higher education are often cited as hard-working, dependable, and committed to the mission of the institution (Rosser \& Javinar, 2003). Putting in long hours and often working without recognition or the hope of tenure, these individuals play essential roles in providing programs for students, supporting the teaching of the faculty, and working to build partnerships and maintain positive relationships with members of the community (Rosser \& Javinar). 
Several studies have uncovered the importance of a healthy campus community to student success at institutions of higher education (Elliott \& Healy, 2001; Nishii, Raver, \& Dominguez, 2000). These studies emphasize that the community experience is important, not only that which students learn in the classroom. To date, the quantity of studies on the job satisfaction levels of administrators in higher education falls far short of the breadth of research related to faculty satisfaction and performance (Johnsrud, 2002; Volkwein \& Parmley, 2000). However, understanding what keeps non-academic employees at institutions of higher education engaged and satisfied with their work is important since the work of the staff has only increased in importance in the last decade and employees on the staff side are those most likely to spearhead any necessary changes in the educational environment (Szekeres, 2006). At the least, the perceptions employees have of their work environment affects their morale, which has been demonstrated to affect their intent to stay in, or leave, a position (Johnsrud, 2002; Johnsrud, Heck, \& Rosser, 2000). Morale affects an employee's performance in ways that are real and measurable, which in turn affects the overall campus culture. There is some indication that morale is related to proficiency and discipline, effectiveness and confidence and optimism with respect to problems and tasks (Wesbrook, 1980; Lindgren, 1982; Johnsrud \& Rosser, 1999). Job satisfaction and job dissatisfaction, aspects of industrial psychology, can be considered as two related but separate concepts according to psychologist Frederick Herzberg.

Job Satisfaction and Job Dissatisfaction

According to his theory on the "motivation to work," Herzberg identifies six factors that contribute to job satisfaction and ten factors that contribute to job 
dissatisfaction (1959). Achievement, growth, recognition, the work itself, responsibility, and advancement are all factors that contribute to job satisfaction, and as a set are termed, "motivators." The ten factors that affect job dissatisfaction, "hygiene" factors, are: company policy and administration, supervision, relationship with a superior, relationship with subordinates, work conditions, salary, relationships with peers, personal life, status, and security. Herzberg's theory postulates that job satisfaction and job dissatisfaction are two separate though related groups of factors. He argues that one cannot improve an employee's satisfaction with his or her job by addressing any of the hygiene factors so instead employers should focus on increasing the levels of the six motivators (Smerek \& Peterson, 2007). Herzberg states, "The opposite of job satisfaction is not job dissatisfaction, but rather, no job satisfaction; and similarly, the opposite of job dissatisfaction is not job satisfaction, but no job dissatisfaction" (Herzberg, 1987, p. 9). Here, Herzberg reinforces that the domains are different, although related. Job satisfaction and job dissatisfaction both contribute to the work environment and employee performance, but have different components. An employee could have low levels of job dissatisfaction and still be overall unhappy at work because of low levels of job satisfaction. Herzberg argues that both spectrums must be addressed to create the most positive work environment; an employee may have given the "work itself" high marks, resulting in high levels of job satisfaction, but if the employee also ranks "company policy and administration" and "work conditions" as subpar, there may be high levels of job dissatisfaction, resulting in an overall lukewarm work environment. Herzberg's duality theory illustrates that employers must address issues in two contexts, 
but acknowledges that the effects of motivators is longer lasting than that of hygiene factors (1987).

Other research has failed to support job satisfaction and job dissatisfaction as disparate variables, but instead has differentiated job satisfaction and morale (Johnsrud and Edwards, 2001). Several studies have identified factors beyond those articulated by Herzberg that have significant effects on job satisfaction, including emotional reaction to a particular job, workload, and department climate (Rosser, 2004). Locke, Fitzpatrick, and White (1987) determined that Herzberg's theory does little to support other research that has been conducted on job satisfaction in a higher education setting. However, Waltman and others, with their research with non-tenure-track faculty, found support for job satisfaction and job dissatisfaction as unique variables (2012). More research is clearly needed to explore those factors which most contribute to job satisfaction of employees in higher education, as well as research to examine the possible independence of job satisfaction and job dissatisfaction as separate variables.

\section{Work Climate in Higher Education}

To provide high quality programs, low student to faculty ratios, and an outstanding living-learning environment, colleges and universities devote a large portion of their annual budget to employing high quality individuals. Without teams of dedicated and hardworking faculty and administrative staff, institutions of higher education would struggle to be effective in their efforts to provide transformational educational experiences (Johnsrud, 2002). In 2003 the Chronicle of Higher Education reported that institutions of higher education in the United States employed over 750,000 full time non-academic employees (Smerek \& Peterson, 2007) - an increase of more than 218\% 
since 1990 (Johnsrud \& Rosser, 1999). By fall 2009, more than 2.8 million people were working as professional staff at public and private universities in the United States, representing $75.6 \%$ of all people employed at institutions of higher education (Digest of Educational Statistics, 2010). Within the Associated Colleges of the South, approximately 3,271 individuals were fulltime professional non-academic employees in Fall 2011 (IPEDS). Figure 3 shows the increase in professional staff, especially those outside of executive/administrative/managerial positions at public and private universities from 1976 to 2011 . While the percentage of faculty members at institutions of higher education has remained relatively flat, the percentage of professional staff employed has almost tripled over a 35-year period. This growth of trained, credentialed, professional staff could indicate a higher emphasis on the quality of services both in and out of the classroom at these institutions. While growth in the number of professional staff members seems to have plateaued in the last decade, these individuals now represent a full quarter of the total employees at public and private colleges and universities in the United States. Unfortunately, colleges and universities are not known for managing this workforce with efficiency or effectiveness (Johnsrud, 2002). 


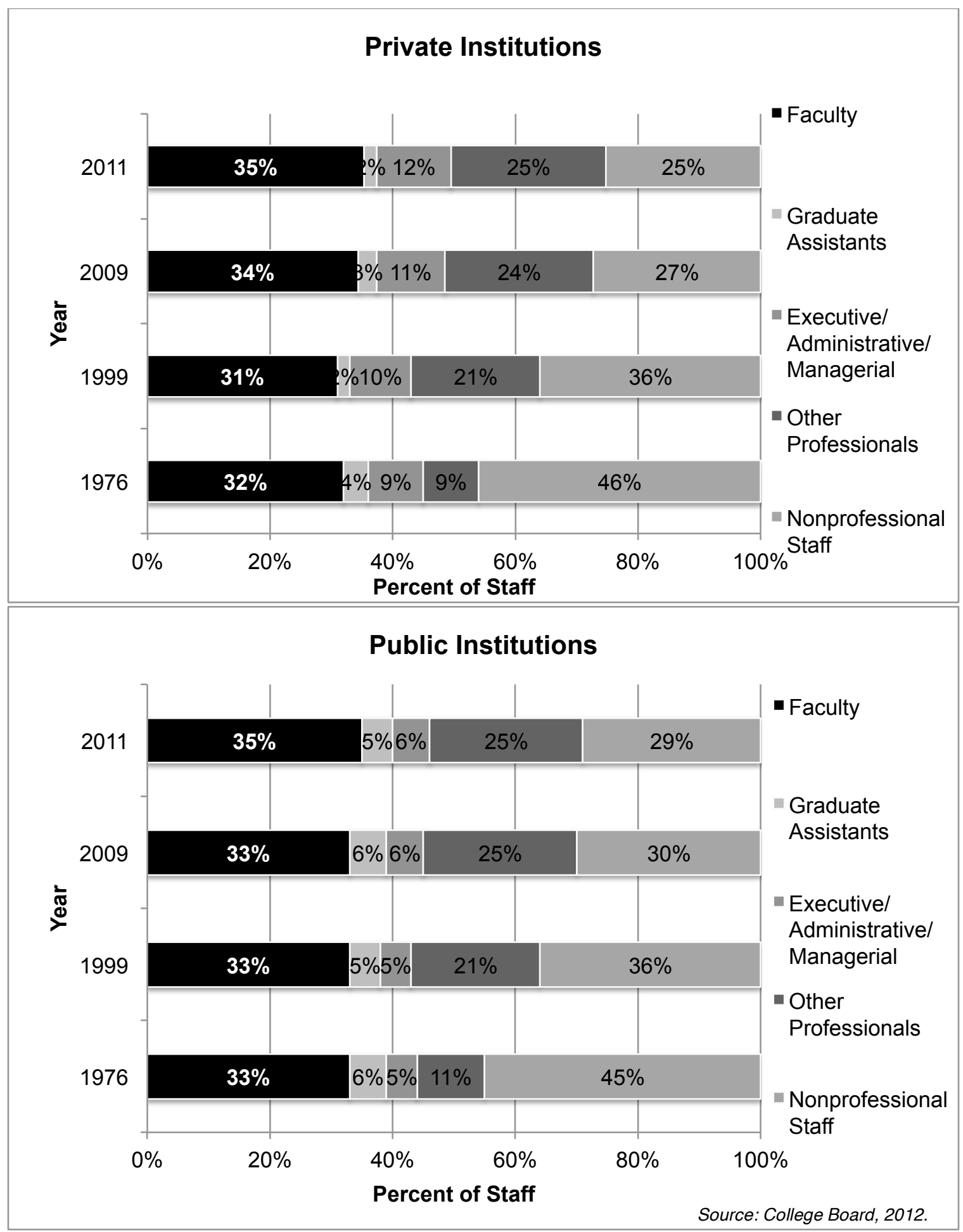

Figure 3. Increase in professional staff in higher education. 
As discussed later in this paper, the literature is mixed regarding the effect of parttime versus fulltime employment on job satisfaction, and it can be argued that fulltime employees face different stressors than part-time employees (Landrum, 2009; Wagoner, 2007); therefore the two groups should be studied differently. In a meta-analysis of studies on the job attitudes of part-time and fulltime employees, Thorsteinston (2003) found results that indicated no difference, others that found higher levels of job satisfaction for part-time workers, and others that identified higher levels of satisfaction for fulltime employees. To limit the variance that may be created by an employee's pay status, this research is limited to fulltime exempt employees only.

Though the research on a direct link between job satisfaction and performance is mixed, it is clear that workers who are satisfied miss fewer days of work, remain in their positions for a longer period of time, and demonstrate positive behavior in the workplace (Brown \& Sargent, 2007). Johnsrud states, "The productivity of faculty and staff and the ability to retain those who are productive is important to campuses, but if campus leaders want to take steps to improve performance and retention, they must be able to identify those issues that matter to those in their employ" (2002, p. 380). Research has suggested that staff and administrators are motivated most by a feeling of appreciation, belonging, and a sense of purpose (Fuller, Hester, Barnett, Frey, \& Relyea, 2006). Clear and consistent multidirectional communication is important for members of the staff to feel included and valued, but at the same time, the voice of staff at institutions of higher education is often limited (Barden, 2005; Rhoades, 2005; Whitchurch, 2007).

As administrators and staff represent a large contingent of the overall employee base at institutions of higher education, it is important to understand ways to maximize 
their productivity and create positive working environments that make it desirable for an employee to remain (Johnsrud, 2002). With substantial costs involved with finding, recruiting, hiring, and training a new employee in higher education, it makes financial sense for institutions to take an intentional approach to understanding both motivator and hygiene factors, and working to improve them, therefore improving their employees satisfaction at work. Further, it has been found that administrators at a campus with discontent or "burned out" employees will have a difficult time recruiting new, talented employees (Houston, Meyer, \& Paewai, 2006; Johnsrud, Heck, \& Rosser, 2000). Staff with lower levels of job satisfaction will have lower morale and an increased likelihood of departing the institution, resulting in increased costs for the school. Wood (1976) argues that while the student experience may be seen as the ultimate barometer for an institution's success, the well-being of an institution may very well be measured by the job satisfaction of its employees.

\section{Extrinsic and Intrinsic Motivation}

Joseph Simplicio (2010) describes two distinct types of workers at colleges and universities - those who take on additional work and responsibilities without flinching, the "Sure, I'll do it," group, and those who "have mastered the ability to do very little and yet survive, and even at times to thrive, within the college system" (p. 136). Simplicio emphasizes that it is important to identify those employees who fall into the first category and nurture them, even though he argues that these individuals are often internally motivated to perform and do it not for recognition or praise, but because of "a desire to prove their worth" (p. 136). In addition to Herzberg's list of motivators, Simplicio advocates for accountability to "guarantee that a college's vision and goals are reinforced 
and that the needs of all students are met" (p. 138). Much of what Simplicio articulates as the motivation found in the high performing employees could be described as "intrinsic" motivation, which is another way of describing Herzberg's motivators (King, 1970). In contrast, King describes extrinsic motivational factors as the "primary determinants of job dissatisfaction” (p. 18) - Herzberg's hygiene factors.

Intrinsic motivation can be defined as "the doing of an activity for its inherent satisfactions rather than for some separable consequence," while extrinsic motivation "is a construct that pertains whenever an activity is done in order to attain some separable outcome" (Ryan \& Deci, 2000, p. 56; 60). A distinct difference in performance has been measured when an individual is acting on intrinsic motivation versus extrinsic motivation, with intrinsic motivation leading to higher and more creative performance and productivity overall (Ryan \& Deci, 2000). Extrinsic motivation requires an outcome that is different from the activity itself, such as salary or pay in the workplace. Intrinsic motivation, on the other had, can be found for some people in the work itself - a sense of pride and happiness that emerges from a job done well. These two types of motivation are separated into Herzberg's categories of "motivator" and "hygiene" factors.

Some researchers who have studied Herzberg's theory have combined job satisfaction and job dissatisfaction and placed them at opposite ends of the same spectrum, the satisfaction-dissatisfaction spectrum (S-D) (King, 1970). Studies by Ewen, Smith, Hulin, and Locke (1966), Graen \& Hulin (1968), and Hinrichs and Mischkind (1967) found that motivators "account primarily for variance on the satisfaction portion of the S-D continuum and [hygiene factors] account primarily for the variance on the dissatisfaction end of the continuum" (King, 1970, p. 23). Others have found that 
teamwork in the work environment (similar to one of Herzberg's hygiene factors, "relationship with peers") has a positive impact on job satisfaction, which goes against Herzberg's idea of dual sets of factors (Volkwein \& Zhou, 2003). Researchers have also found that for academic employees at institutions of higher education, salary, work hours, and colleague support were the largest predictors of an employee's overall level of stress, and that stress level was negatively correlated with job satisfaction (Hagedorn, 1994).

Studying the work environment and an employee's satisfaction with his or her work is important, within and outside of the context of education. Several factors identified by Herzberg have been positively correlated with job satisfaction in other studies, including age (Gibson \& Klein, 1970; Siassi, Crocetti, \& Spiro, 1975; Warr, 1992). The research on gender and job satisfaction is mixed, with some studies demonstrating that women have consistently higher levels of job satisfaction than men, one study demonstrating that male faculty members exhibit higher levels of job satisfaction than their female counterparts (Bozeman \& Gaughan, 2011), and others showing no gender differences (Eleswed \& Mohammed, 2013; Oshagbemi, 2003). The results regarding the impact of length of service on job satisfaction levels are also mixed, as at least one researcher identified a "U-shaped" curve of association between the two variables (Ronen, 1978). Ronen's research (1978) found that employees demonstrated high levels of initial job satisfaction that waned in the second through fifth years in a position but then rebounded in subsequent years; when plotted on a graph with job satisfaction on the y-axis and years in position on the x-axis, the resulting line had a "U" shape. Others found that length of service made no significant difference in an individual's level of job satisfaction, but when a group's overall length of service was 
increased, so was job satisfaction (Wharton, Rotolo, and Bird, 2000). Ronen (1978) noted that job satisfaction was positively correlated with an individual's level of occupation, a result confirmed by others (Miles, Patrick, \& King, 1996; Oshagbemi, 2003). Lefkowitz (1994) found that differences in job satisfaction levels were eliminated when controlling for, among other personal characteristics, age, gender, level of education.

A person's work comprises a significant portion of an individual's time, energy, and effort, and as a result creating a positive work experience is imperative (Kalleberg, 1977). Hoppock (1935) echoes Herzberg, effectively describing overall job satisfaction as the sum of job satisfaction factors and job dissatisfaction factors, and that it is possible for "a person to balance [specific] satisfactions against the specific dissatisfactions and thus to arrive at a composite satisfaction with the job as a whole" (Kalleberg, 1977, p. 126). 


\section{CHAPTER III \\ METHODOLOGY}

\section{Introduction}

The purpose of this study was to explore factors contributing to the job satisfaction levels of fulltime exempt employees at liberal arts institutions within the Associated Colleges of the South (ACS). This study builds upon the research conducted by Smerek and Peterson (2007) exploring the validity of Herzberg's theory of motivation in a higher education setting. To examine the job satisfaction levels of non-academic employees at the institutions that comprise the ACS, a survey was distributed electronically to participants, with paper copies available upon request. The survey was based on the instrument designed and used by Smerek and Peterson (2007) for their study of 2,500+ non-academic business employees at a large university. The items were grouped based on the factors identified by Herzberg as motivators (seven sub-categories) and hygiene factors (six sub-categories). Table 3 in Appendix B lists the items used to measure each motivator or hygiene factor, as well as the items used to assess the dependent variable job satisfaction. The study by Smerek and Peterson (2007) employed a ten-point Likert scale to assess each variable in the survey, using parameters of “strongly disagree" to "strongly agree." Social scientists (Maurer \& Pierce, 1998) have identified the Likert scale as a reliable, and according to Dillman, Smyth, and Christian (2009) the optimal scale length is four to five categories. Scales with four or five 
categories have been shown to have higher levels of reliability and validity (Dillman, Smyth, \& Christian, 2009). In an effort to increase internal reliability and validity levels, this survey instrument used a five-point Likert scale rather than the ten-point scale from the Smerek and Peterson (2007) study. Additionally, some items were adapted to fit the population surveyed, including the change of "University" to "institution" to reflect the type of working environment of those surveyed.

Two research questions guided this study of professional staff members. With relevant hypotheses, they are:

1. Do the factors within the perceived work environment predict job satisfaction? $\mathrm{H}_{1}$ : There is a significant predictive relationship between the motivators (intrinsic factors) (clarity of mission, good feelings about organization, opportunity for advancement, professional growth opportunities, recognition, responsibility, work itself) and the dependent variable, job satisfaction.

2. Is Herzberg's duality theory of motivators and hygiene factors supported in this higher education context?

$\mathrm{H}_{2}$ : Herzberg's duality theory of motivators and hygiene factors will be not be supported in this context because a significant predictive relationship will be found between hygiene factors and the dependent variable, job satisfaction.

\section{Population}


The population for this study was all fulltime professional staff at institutions of higher education within the Associated Colleges of the South (ACS) consortium. The mission of the ACS is "to make the case for liberal arts education and to strengthen academic programs of the member institutions" (Associated Colleges of the South, n.d.). Since 1991, this group of 16 institutions has worked in cooperation to improve the educational experience for students at their respective campuses and institutions within the consortium are consistently recognized for their excellence. These institutions have joined the ACS to share resources, make a case for liberal arts education, and pledge to work together to increase the effectiveness and efficiency of their campus operations (Associated Colleges of the South, n.d.).

Within the ACS, as for many colleges and consortia in the United States, staff represent the largest employee group at the institution (Rosser \& Javinar, 2003). As of fall 2011, the ACS collectively employed over 10,000 people, with over $6,382(60.1 \%)$ of them serving in full time non-faculty professional roles. On average, each school employs almost 400 fulltime professional staff (U.S. Department of Education, Institute of Education Sciences, National Center for Education Statistics, 2012). Totaling more than 3,271 professionals, this group represents more than $40 \%$ of the individuals employed at the 16 institutions. The relationship of these institutions to one another through their membership in a consortium creates an opportunity to communicate swiftly and easily with institutional leadership to recruit participants for this study. This consortium represents a sample of high quality liberal arts institutions and a sample convenient for extending the work of Smerek and Peterson (2007) in a different environment. In short, the ACS was selected for study due to the distinguished nature of 
the institutions involved, the strength of the consortium, and access to the desired participants.

A meta-analysis of studies (Thorsteinston, 2003) on the job attitudes of fulltime and part-time workers revealed no overall differences in the job satisfaction levels between fulltime and part-time employees. However, in the literature review of this study, Thornsteinston (2003) indicates that the results of similar studies have been mixed, with some indicating higher levels of job satisfaction for those in part-time positions (Barker, 1993; Eberhardt \& Shani, 1984; Peters, Jackofsky, \& Salter, 1981; Sinclair, Martin, \& Michel, 1999; Wotruba, 1990), others revealing no difference in job satisfaction levels between fulltime and part-time employees (Krausz, Safie, \& Bidermann, 2000; Levanoni \& Sales, 1990; Logan, O’Reilly, \& Roberts, 1973; Steffy \& Jones, 1990), and a number of studies that found higher levels of job satisfaction for those employees in fulltime positions (Miller \& Terborg, 1979; Shockey \& Mueller, 1994). According to this body of research, job satisfaction levels for fulltime employees within the ACS institutions may be very different from individuals employed part-time, contributing to the decision to limit this research to fulltime employees. Additionally, the target population of fulltime, professional staff and administrators eliminates those employees with teaching responsibilities and includes only those individuals who work fulltime for the institution. The researcher communicated directly with the director of Human Resources at each participating institution to most clearly identify the population being studied. Hourly employees, such as housekeeping and facilities management staff, were excluded from this study but represent a group for future study in the area of job satisfaction in higher education. 
Recognizing that some fulltime professional staff may have the responsibility and opportunity to teach one or more classes during the academic year, items were included within the survey instrument to delineate those with no teaching responsibility. Employees within the scope of this study include those in administration, such as deans, provosts, and individuals at the director level, as well as professional staff with titles such as analyst, advisor, counselor, and specialist. Titles may vary significantly between institutions, so this list of titles is not exhaustive; all fulltime professional staff and administrators will be eligible to participate in the study and will be delivered an email invitation to complete the online survey instrument from their director of Human Resources. Employees eligible for this study include those who may work directly with students and/or may have supervisory responsibility of other employees within their unit/department.

Employees surveyed in this research could have a broad range of terms of service to the institution, and therefore information was collected on length of service to the institution to identify possible effects of each of this variable. Additionally, information was collected on the employees' specific work unit/department as within-institution differences may be explained in part by that variable.

Sample

Distributing the survey electronically allowed for the entire population of fulltime professional staff within the ACS to be included in the study. Four institutions agreed to participate in the study. With the support of Human Resource Administrators and Directors of Institutional Research at these four ACS institutions, the digital survey was delivered to each campus employee within the parameters of the research. The sampling 
frame for this research was the group of institutions from within the ACS who agreed to participate by sending their fulltime professional employees a link to the online survey instrument. All fulltime, exempt, professional staff and administrators were eligible for participation in the survey, regardless of title or specific position. The primary sampling unit was each individual institution.

The survey instrument was slightly personalized for more personal distribution at each school. This personalization entailed changing the title on the Informed Consent page to include the name of the specific institution, as well as the inclusion of that institution's name in the header of each page of the survey instrument. Information distributed to each participating institution in advance of the research included an identification of the target population, a description of the purpose and scope of the study, a description of the potential benefits to the institution by participating, a copy of the IRB approval and informed consent document, including anticipated risk, as well as details of the study's timeline and duration. Contact information for the primary investigator and faculty advisor, as well as the University of Louisville Human Subjects Protection Program was also included.

According to Green (1991), a study should incorporate a sample size of $N \geq 50+$ $8(p)$ (with $p=$ number of independent variables). For this study, with twenty-one independent variables (six personal characteristics, two work characteristics, seven motivator subscales, and six hygiene factor subscales), a sample size of 218 is the minimum recommended to complete regression analyses. To avoid an overestimation of $R$, most researchers suggest a ratio of predictors to sample size of 1:30, or at least 1:15 (Pedhazur, 1997). Using the 1:15 ratio, the twenty-one independent variables in this 
study would suggest a sample of at least 315 employees. With a total population of executive and professional staff greater than 3,000 and a range of 58-548 individual employees at each institution, the response goal for the current study was an average of 61.2 respondents from each institution. Table 1 depicts the executive and professional staff counts at each ACS institution during the 2011-2012 school year as reported to the National Center for Educational Statistics. The names of individual institutions have been masked to preserve anonymity of both institutions and respondents. 
Table 1

Number of Employees at ACS Institutions

\begin{tabular}{|c|c|c|c|}
\hline \multirow{4}{*}{$\begin{array}{l}\text { Institution (masked } \\
\text { for confidentiality) }\end{array}$} & Executive & Other Professional & \multirow[t]{4}{*}{ Total Staff } \\
\hline & Administrative and & FTE Staff & \\
\hline & \multicolumn{2}{|l|}{ Managerial FTE } & \\
\hline & \multicolumn{2}{|l|}{ Staff } & \\
\hline 1 & 87 & 449 & 536 \\
\hline 2 & 32 & 26 & 58 \\
\hline 3 & 43 & 126 & 169 \\
\hline 4 & 45 & 263 & 308 \\
\hline 5 & 67 & 128 & 195 \\
\hline 6 & 96 & 59 & 155 \\
\hline 7 & 14 & 91 & 105 \\
\hline 8 & 50 & 242 & 292 \\
\hline 9 & 20 & 113 & 133 \\
\hline 10 & 78 & 35 & 113 \\
\hline 11 & 76 & 111 & 187 \\
\hline 12 & 32 & 83 & 115 \\
\hline 13 & 120 & 159 & 279 \\
\hline 14 & 77 & 170 & 247 \\
\hline 15 & 53 & 95 & 148 \\
\hline 16 & 74 & 157 & 231 \\
\hline
\end{tabular}

Source: National Center for Educational Statistics, 2011-2012 


\section{Research Design}

This study was conducted using a non-experimental research design, as the groups of employees at each institution were pre-existing. Additionally, the dependent variables assessed in the research were not manipulated through the survey of participants. The survey instrument was developed and distributed using the online tool Qualtrics.

Electronically distributed surveys have been shown to be an effective means of collecting information, though they do have their drawbacks. In their research on mail versus email survey solicitation, Holland, Smith, Hasselback, and Payne (2010) found no statistically significant difference in the number of responses to postal mail surveys compared to electronically distributed surveys. The authors did determine the postal surveys cost as much as 17 times the amount required to produce, distribute, collect, and analyze the electronic surveys. "The fast, efficient and often 'free' electronic survey has many advantages over the traditional postal data collection method, including ease of analysis for what can be vast amounts of data" (McPeake, Bateson, \& O’Neill, 2014, p. 26). Given the large size of the sample and the geographic distribution of campuses under consideration, electronic distribution of the survey instrument was determined to be the best approach.

Participants were invited to take part in the research with an initial introductory email, including a link to the survey. The survey was available for two weeks, with participants receiving a reminder email at the end of the first week, and a final reminder email two days before the close of the survey. 


\section{Instrument}

Variables related to personal (age, gender, length of employment, level of education, minority status, and salary) and work characteristics (area of employment and number of fulltime professional staff in the department), as well as the motivators and hygiene factors described in Herzberg's theory, were measured using an adaptation of the instrument employed by Smerek and Peterson (2007) in order to assess the relevance of their model in this context. The complete original instrument used by Smerek and Peterson (2007) in their study of business office employees was unavailable for use in this study, and therefore the instruments validity and reliability could not be independently verified. However, this research builds directly upon the information available from the Smerek and Peterson (2007) study and will assist in the creation of a survey instrument to reliably assess the job satisfaction levels of fulltime professional employees in higher education.

Developed in cooperation with an organizational development specialist and a customer service-consulting firm, Smerek and Peterson's survey (2007) was distributed electronically to more than 2,500 individuals. For the purpose of the research described in this paper, the survey distributed to potential participants was titled "Staff Survey on Workplace Climate.” Alterations made to the original Smerek and Peterson (2007) survey included changes in language to recognize that employees from multiple departments would complete the survey. Work unit, for the purpose of the study that is the focus of this paper, is defined as the employee's status as a member of the administration or as a member of the exempt professional staff. Studies have demonstrated that a correlation may exist between administrative area and job 
satisfaction (Glick, 1992). However, a limitation of the study may be confusion on the part of participants regarding the definition of this variable.

The research described in this paper collected information regarding the size of an employee's work unit as this factor may significantly predict job satisfaction.

Additionally, in variance to the Smerek and Peterson research (2007), survey participants were not questioned regarding their union membership as no employee unions currently exist within the ACS. The variables gender and minority status (derived from two items on race and ethnicity) were treated as dichotomous variables within the study. A variable missing from the work completed by Smerek and Peterson (2007) but included in this study was length of service, which other studies have demonstrated to be positively correlated with job satisfaction (Bamundo \& Kopelman, 1980). The item, "Overall, how would you rate your supervisor?" was changed to "Overall I would give my supervisor a high rating" to better fit the Likert scale used by the remaining items. Smerek and Peterson's research (2007) centered on business employees and the language of their survey instrument was tailored to that population. In order to broaden the range of the survey to include administrators and staff from various areas of the institutions, the item "My customers recognize my good work," was adapted to "Those whom I serve recognize my good work." Similarly, the items "Imagine your ideal job. How well does your current position compare to that ideal job?" "Overall how satisfied are you with your job" and "Consider all the expectations you had when you started your current job. To what extent does your current job fall short or exceed those expectations?" were adapted to fit a Likert scale response by changing them to "Imagine your ideal job. My current position compares favorably to my ideal job," "I am satisfied with my job," and 
"Consider all the expectations you had when you started your current job. My job exceeds these expectations," respectively. The composite of an individual's response to these three items created an overall job satisfaction rating that was used as the dependent variable.

All fulltime professional staff members employed at the four ACS institutions received an email invitation to complete the survey. The online survey tool Qualtrics was used to develop and distribute the survey. To reach all fulltime exempt, professional, non-academic employees at the ACS institutions, support was gathered from individuals in charge of institutional research, human resources, and institutional presidents, all of who stand to be able to make positive use of the information collected through this research. The raw data collected through the survey was maintained in a confidential file by the researcher with information provided to institutional administrators only in aggregate form by institution with all individually identifiable information removed before distribution.

\section{Data Collection}

Prior to the distribution of the research instrument, the IRB at the University of Louisville was provided with a full description of the research plan and survey instrument for approval. The informed consent form developed through the IRB process was distributed to study participants as the first page of the electronic survey. The researcher contacted the director of human resources or an equivalent administrator at each institution for assistance in distributing the survey instrument to the appropriate group of fulltime exempt professional staff members. Survey participants received an initial invitation to participate in the study, expressing the researchers appreciation for their 
participation, and including a link to the Qualtrics online survey. Each employee was eligible to complete the survey one time, as the survey was limited to one response per IP address. Following the initial invitation email, potential participants were contacted one week later, and once more two days before the close of the survey. Based on current research findings that more than three outreach attempts can be distasteful to potential participants (Cook, Heath, \& Thompson, 2000), additional attempts were avoided. In total, the survey was open for a two-week period.

\section{Data Analysis}

Since the goal of the research was to help professionals better predict and understand job satisfaction of professional staff at their institutions, survey responses were analyzed using hierarchical multiple regression. The basic assumptions of regression - linearity, homoscedasticity, and normality of residuals - were examined as part of the data analysis by examining the histogram chart of the regression standardized residual, the P-P plot of regression standardized residual, and a scatterplot of the regression standardized residual versus the regression standardized predicted value. Prior to the implementation of hierarchical multiple regression, an analysis of the internal reliability of each factor's scale was assessed using Cronbach's alpha. The items asked to assess each motivator, hygiene factor, and the dependent variable job satisfaction were analyzed using the reliability analysis feature within SPSS. The items for each factor were entered as a group in SPSS which produced an overall alpha level for the group of items as well as the corrected item-total correlation and Cronbach's alpha if deleted. This procedure was repeated for each factor/group of items. The corrected item-total correlation illustrated the correlation between each individual item and the sum of the 
remaining items. A correlation less than .30 would indicate that consideration should be given to removing the item (de Vaus 2004). The "Cronbach's alpha if item deleted" showed how the alpha level would change if the particular item were deleted. Since there was very little change in the alpha levels by removing any of the items, all were kept for analysis. This reliability analysis allowed the researcher the opportunity to identify factors detracting from the amount of variance explained and to remove them from the model. All were maintained.

The variables regarding race and ethnicity were combined and recoded to create the nominal dummy variable "minority_recode" where $0=$ "yes" for all individuals who answered that they were either Hispanic, American Indian or Alaska Native, nonHispanic, Asian, non-Hispanic, Black or African-American, non-Hispanic, Native Hawaiian or Other Pacific Islander, non-Hispanic, Non-Resident Alien, or Two or more Races, non-Hispanic. Individuals were assigned the dummy code of $1=$ "no" for the variable "minority_recode" if they answered that they were not Hispanic on the ethnicity item and that they were White, non-Hispanic on the race item or if they chose the "prefer not to respond" option. Using participant responses to the item regarding job category, the nominal dummy variable "job_type" was created where " 0 " = administration and "1" $=$ exempt professional staff.

Hierarchical multiple regression was chosen as the preferred analysis due to the large number of predictors in the model. This type of analysis enabled the researcher to enter the factors into the analysis as groups (personal characteristics, work characteristics, motivators, and hygiene factors). A mean composite score was created for each factor, as well as an overall mean composite score for the motivators as a group, the hygiene 
factors as a group, and the dependent variable job satisfaction. Using a mean composite score maintained the measurement scale used by participants in the survey.

After the reliability analysis was completed, the researcher used hierarchical multiple regression to analyze the predictive value of personal characteristics (age, gender, length of employment, level of education, minority status, and salary), work characteristics (area of employment and number of fulltime professional staff in department), motivators (intrinsic factors) (clarity of mission, good feelings about organization, opportunity for advancement, professional growth opportunities, recognition, responsibility, work itself), and hygiene (extrinsic) factors (effective senior management, effective supervisor, good relationships with co-workers, presence of core values, satisfaction with salary, satisfaction with benefits). Using hierarchical multiple regression allowed the researcher to see the change in $R^{2}$ (the amount of variability in the dependent variable accounted for by the independent variables) as each of these groups of factors were added to the model. The $F$-values from the accompanying ANOVA analysis were used to determine statistical significance.

\section{Limitations}

Limitations to the study may include a low response rate to the survey by nonacademic staff from ACS institutions or data that yield inconclusive results. While the results of this research may provide the institutions under study with valuable information, further research is needed to generalize the results to a more diverse set of institutions of higher education. There may be temporal effects unexplored and unaccounted for within this study that could be studied to add validity to the results by 
repeating the same study with the same population over time at varying times throughout the year.

Additionally, as in the work of Smerek and Peterson (2007), this study does not measure employee levels of job dissatisfaction. Though Herzberg's (1959) theory identifies job satisfaction and job dissatisfaction as distinct variables, this study is limited to the exploration of factors related only to job satisfaction. 


\section{CHAPTER IV \\ RESULTS OF THE STUDY}

This study examined the effects of four independent variables (personal characteristics, work characteristics, motivators, and hygiene factors) on one dependent variable, job satisfaction. The scores of three items related to job satisfaction were combined and averaged to form the measure of the dependent variable. The three items each used a five-point Likert scale response set with $1=$ Strongly Disagree and $5=$ Strongly Agree. Using three items to form a mean composite score allowed the researcher to maintain the same scale used by participants, with a highest possible score of 5 and a lowest possible score of 1 . Fulltime professional staff at four participating institutions received email invitations to complete the survey.

\section{Participants and Data Collection}

All fulltime professional staff members $(N=680)$ at the four participating ACS institutions were invited to complete an electronic survey via an email from either the Human Resource Director or the Director of Institutional Research at their institution. Following the initial email invitation, potential participants received two reminders to complete the survey which was open for a total period of two weeks. A total of 375 individuals participated in the electronic survey representing a response rate of $55.1 \%$ $(375 / 680=0.551)$. The institutional response rates ranged from a high of $91 \%$ to a low

of $41 \%$. The breakdown of each institution's participation is featured in Table 2 on the following page. The names of participating institutions have been removed in an effort to 
preserve anonymity and disconnect these data from other available employee information. Some data were missing from the survey results, but the percentage was small - an average of $6.8 \%$ of the data per construct. No overall pattern was detected within the missing data points, and the highest percentage of missing cases was from the items toward the end of the survey, a possible indication of survey fatigue. An above average proportion of missing data came from responses to the item regarding effective supervision that could be related to employee discomfort with rating their supervisor, even in an anonymous online survey.

Table 2

Job satisfaction scores

Mean Job

Satisfaction

\begin{tabular}{cccc} 
Institution & No. of Participants & Response Rate & Composite Score \\
\hline Institution A & 118 & $48 \%$ & 3.3 \\
Institution B & 121 & $91 \%$ & 3.7 \\
Institution C & 56 & $53 \%$ & 3.5 \\
Institution D & 80 & $41 \%$ & 3.5
\end{tabular}

Data Analysis

The data collected from the online survey tool were exported and analyzed using SPSS. Similar to the analysis conducted by Smerek and Peterson (2007), data analysis included examination of descriptive statistics, comparison of means, reliability analysis, and hierarchical multiple regression. A preliminary analysis was conducted to assure the assumptions of normality, linearity, and homoscedasticity were not violated by examining the histogram chart of the regression standardized residual, the P-P plot of 
regression standardized residual, and a scatterplot of the regression standardized residual versus the regression standardized predicted value.

\section{Descriptive Statistics}

The demographic information received from survey participants was analyzed using frequencies, means, standard deviations, and range statistics. Table 4, below and in Appendix C, provides a list of these data in full. More women (49.1\%) participated in the survey than men $(33.3 \%)$, and $17.6 \%$ of individuals declined to indicate their gender. Participants in the 50-54 age range responded more frequently than others $(\mathrm{N}=50 ; 16 \%)$. The majority of the survey participants (89.4\%) described themselves as White, nonHispanic, while $10.6 \%$ classified themselves as being from a minority group, the largest portion being Hispanic or Latino (8.8\%). Two in five survey participants (40.8\%) had completed at least a bachelor's degree, and a significant percentage (35.4\%) had fulfilled the requirements for a master's degree. Almost ten percent of survey respondents had completed a degree (i.e. PhD, EdD) beyond a master's.

Almost one in five survey respondents (19.7\%) had been employed at their institution for less than two years, and a total of $37.6 \%$ of participants had been employed by their institution for less than five years. Most survey participants (51.5\%) reported working with seven or fewer other professional staff in their offices, and the majority $(85.3 \%)$ held no instructional role. Finally, the largest single group of participants (42.7\%) reported receiving an annual salary between $\$ 25,001$ and $\$ 50,000$.

More exempt professional staff (69.1\%) participated in this research study than individuals who classified themselves as working in administration (30.9\%). For the purposes of this survey, those working in the administration were individuals with 
supervisory responsibility and, in some cases, oversight of entire departments or the institution as a whole. Exempt professional staff are those individuals reporting to

Table 4

Demographic summary

\begin{tabular}{lccccccc}
\hline & $\mathrm{N}$ & Range & Min. & Max. & Mean & SE & SD \\
\hline Age & 315 & 9 & 1 & 10 & 5.62 & .135 & 2.4 \\
Gender & 338 & 2 & 1 & 3 & 1.72 & .033 & .61 \\
Length of Employment & 313 & 7 & 1 & 8 & 3.83 & .129 & 2.28 \\
Level of Education & 313 & 7 & 1 & 8 & 4.88 & .096 & 1.70 \\
Minority Status & 290 & 2 & 1 & 3 & 1.91 & .020 & .34 \\
Salary & 306 & 7 & 1 & 8 & 2.75 & .069 & 1.21 \\
Area of Employment & 322 & 1 & 0 & 1 & .696 & .026 & .46 \\
No. Prof. Staff in Office & 261 & 0 & 0 & 80 & 10.67 & .648 & 10.5 \\
\hline
\end{tabular}

members of the administration, often in direct service roles

Reliability Analysis

To examine the internal consistency between the items used to collect data on each construct in the conceptual model, a reliability analysis was conducted using Cronbach's alpha. According to de Vaus (2014), researchers should consider removing items from composite scores if the corrected total-item correlation is less than 0.30 . In this study none of the items used in the survey produced a corrected-item correlation less than this margin and therefore all items were included in the analysis. A Cronbach's alpha score of at least 0.70 is necessary to consider a measure reliable (de Vaus, 2014), 
and in this study all alpha levels exceeded this threshold. A summary of the reliability analysis follows. Cronbach's alphas for the motivators were: "clarity of mission" (five items; $\alpha=.810$ ); "good feelings about organization" (five items; $\alpha=.828$ ); "opportunities for advancement" (four items; $\alpha=.810$ ); "professional growth opportunities" (five items; $\alpha=.870$ ); "recognition" (five items; $\alpha=.895$ ); "responsibility" (five items; $\alpha=.828$ ); “work itself” (four items; $\alpha=.892$ ). Cronbach's alphas for the hygiene factors were: “effective senior management" (three items; $\alpha=.954$ ); "effective supervisor" (fifteen items; $\alpha=.975$ ); "good relationships with co-workers" (eight items; $\alpha=.924) ;$ "presence of core values" (three items; $\alpha=.780$ ); "satisfaction with salary" (five items; $\alpha=.837$ ); "satisfaction with benefits" (four items; $\alpha=.829$ ). Cronbach's alpha for the dependent variable job satisfaction was also high (three items; $\alpha=.876$ ). High Cronbach's alpha levels for each set of items used to measure the model factors indicate high internal consistency within the items. Similarly, the analysis demonstrated only slight changes in Cronbach's alpha if any of the items were removed from analysis. So slight was the change that all items were maintained for analysis. Table 5 in Appendix D lists the Cronbach's alpha level for each group of items, as well as the corrected-item correlation and Cronbach's alpha for each if deleted.

\section{Inferential Statistics Analysis}

Hierarchical regression was employed to determine the amount of variability in job satisfaction accounted for by each set of predictors. Factors were aggregated into four groups (personal characteristics, work characteristics, motivators, and hygiene factors) to fit with the conceptual model then entered for analysis in SPSS. In step one of the hierarchical regression analysis, all of the variables that comprise personal 
characteristics (age, gender, length of employment, level of education, minority status, and salary) were entered into the model. This model was not statistically significant. In the second step of the regression analysis, all variables that comprise work characteristics (area of employment and number of fulltime professional staff in the department) were added to the model. This model was not statistically significant. The variables that represent personal characteristics and work characteristics did not significantly account for any of the variability within the dependent variable job satisfaction. In step three of the regression analysis, all variables identified as motivators (clarity of mission, good feelings about the organization, opportunity for advancement, professional growth opportunities, recognition, responsibility, and work itself) were added to the model. This model was statistically significant $(F(15,195)=28.06, p<0.00)$ and explained a total variance of $65.9 \%$. The addition of the motivator variables resulted in an increase of $64.4 \%$ total variance explained after controlling for personal and work characteristics $\left(R^{2}\right.$ change $=.644 ; F(7,195)=56.62, p<0.001)$. The addition of all the hygiene factor variables (effective senior management, effective supervisor, good relationships with coworkers, presence of core values, satisfaction with salary, satisfaction with benefits) in step four of the regression model increased the amount of variability explained by less than three percent $\left(R^{2}\right.$ change $\left.=0.02 ; F(6,189)=2.21, p<.001\right)$, but did account for additional variability. In the final model, five of the individual predictor variables were statistically significant. The first four variables were positively related, and the fifth was negatively related to job satisfaction. The responsibility variable recorded the highest Beta value $(\beta=.27, p<.001)$, followed by work itself $(\beta=.23, p<.001)$, effective supervisor $(\beta=.21, p<.05)$, recognition $(\beta=.152, p<.05)$, and presence of core values 
$(\beta=-.13, p<.05)$. This final model was statistically significant $(F(21,189)=21.42, p<$ 0.001 ) and explained a total variance of $67.1 \%$. Table 5 in Appendix D provides the results of the hierarchical multiple regression analysis in detail.

\section{Hypotheses}

Two research questions guided this study:

1. Do the factors within the perceived work environment predict job satisfaction? $\mathrm{H}_{1}$ : There is a significant predictive relationship between the motivators (intrinsic factors) (clarity of mission, good feelings about organization, opportunity for advancement, professional growth opportunities, recognition, responsibility, work itself) and the dependent variable, job satisfaction.

2. Is Herzberg's duality theory of motivators and hygiene factors supported in this higher education context?

$\mathrm{H}_{2}$ : Herzberg's duality theory of motivators and hygiene factors will be not be supported in this context because a significant predictive relationship will be found between hygiene factors and the dependent variable, job satisfaction.

The results of the regression analysis support the first hypothesis as the motivators (intrinsic factors) accounted for $64.4 \%$ of the variance in the dependent variable job satisfaction. A statistically significant predictive relationship was found between the motivators and job satisfaction.

The results of the analysis also supported the second hypothesis. Herzberg's duality theory of motivators and hygiene factors was not supported as the amount of 
variance in job satisfaction increased by $2.1 \%$ when hygiene factors were added to the model. An analysis of the implications of these results is presented in the following chapter. 


\section{CHAPTER V \\ DISCUSSION, IMPLICATIONS, AND CONCLUSIONS}

This study examined the ability of four groups of factors to predict the job satisfaction levels of fulltime, exempt, professional staff at four institutions of higher education within the Associated Colleges of the South consortium. Based on a similar study of professionals in higher education conducted by Smerek and Peterson (2007), this study used hierarchical multiple regression to determine the amount of variability explained by each group of factors according to the conceptual model. The conceptual model for this study, as well as the study by Smerek and Peterson, was based on the theory of Frederick Herzberg (1959), an industrial organizational psychologist who described job satisfaction and job dissatisfaction as disparate variables. Herzberg's theory postulated that even though employees could have high levels of job satisfaction, they may still not be happy in the workplace due to high levels of job dissatisfaction. Similarly, employees with low levels of job dissatisfaction may still be unhappy in the workplace if they experience low levels of job satisfaction. Herzberg identified factors contributing to job satisfaction as "motivators" and those that affected job dissatisfaction as "hygiene" factors. In addition to these two groups of factors, this study examined the predictive value of personal characteristics and work characteristics. This research explored the validity of Herzberg's theory in a higher education context and identified which factors within the conceptual model were the best predictors of job satisfaction. 


\section{Descriptive Statistics}

The descriptive statistics of this study's results showed several trends within the surveyed population. The vast majority of individuals (85.6\%) who responded had completed a four-year college degree. While this percentage is high, it may still surprise some in institutional leadership positions that almost $15 \%$ of those individuals working as fulltime professional staff members charged with helping students succeed in college have not yet completed a college degree. The level of education completed was not a significant predictor of job satisfaction and an analysis of means revealed no clear pattern.

The transitory nature of higher education professionals was exhibited within the survey sample as almost one in five (19.5\%) survey respondents had been employed by their institution for less than two years, and almost double that number (37.6\%) had been employed for less than five years. Institutional leadership should note that those individuals employed less than two years $(M=3.67)$ and between two and five years $(M$ $=3.55)$ exhibited higher mean levels of job satisfaction than those employed five to seven years $(M=3.31)$. The group with the highest mean score for job satisfaction $(M=3.79)$ was comprised of those employees with between sixteen and twenty years of service to the institution. These job satisfaction scores should indicate to employers that even more opportunities for professional development, advancement, and engagement should be made available for those individuals employed between five and fifteen years. Opportunities should be provided for employees with longer service records to mentor and support those approaching five years on the job in an attempt to sustain higher levels of job satisfaction. 
Those survey participants who described themselves as part of a racial or ethnic minority exhibited lower levels of job satisfaction $(M=3.30)$ than other survey participants $(M=3.61)$. Though racial minority status alone did not predict a statistically significant portion of the variance within job satisfaction levels, the difference in means bears investigating by leaders at participating institutions.

Top income earners from this survey's sample reported higher mean levels of job satisfaction than their colleagues, but annual income did not predict a large amount of variance within job satisfaction levels. These results suggest that while income may be associated with higher levels of job satisfaction, it is not an independent predictor of overall satisfaction levels.

Almost no differences in job satisfaction levels were obtained between those individuals who identified as male $(M=3.59)$ and those who identified as female $(M=$ 3.57) in this survey. Additionally, age did not significantly predict levels of job satisfaction, and a comparison of means revealed no pattern. The lack of disparity along lines of gender and age should be an encouraging result to those in positions of leadership at participating institutions.

Reliability Analysis

The coefficient alpha of each of the construct mean composite scores was examined to assess reliability. Each composite had high levels of internal consistency represented by high coefficient alpha scores for the items pertaining to each construct, and therefore all variables were maintained for analysis. Although the original survey instrument and reliability estimates were not available from Smerek and Peterson (2007), the items used and adapted from their publications demonstrated high levels of reliability. 
These levels suggest that the constructs may be used in the future as measures of job satisfaction in the higher education workplace.

\section{Inferential Statistics Analysis}

In the final hierarchical multiple regression model, five predictor variables were statistically significant. The predictor "responsibility" had the highest Beta value $(\beta=$ $.27, p<.001)$. This Beta value suggests that if responsibility scores could be increased by one standard deviation $(S D=.84)$, overall job satisfaction scores would be likely to increase by .27, which on a scale of 1 to 5 may be significant to some employees and their supervisors. This result suggests that employers interested in increasing the overall job satisfaction levels of their employees should focus on providing their employees with increased control over their work and creating more opportunities for their opinions to be considered. Fuller, Hester, Barnett, Frey, \& Relyea (2006) support the positive influence of this variable, stating that staff place more importance on someone recognizing their contributions than their faculty colleagues, and value opportunities to voice their opinions over increases in university prestige. This construct also had the second highest Beta value in the Smerek and Peterson (2007) study, and tied with the predictor "effective supervisor" in their study, which was also a statistically significant predictor in this model.

Equipping employees with the necessary tools they need to do their work, and providing the right kind of physical environment in which they can work are also important aspects of the "responsibility" construct, and may make an important difference in employee levels of job satisfaction. Biemiller (2008) paints a stark contrast 
between the work environment and overall job satisfaction of employees who work in a cubicle-style office setting versus those who work in an old building with lots of character, close to quality coffee options and manicured landscapes. In his study, college employees were much more likely to choose a smaller, quirkier space near the heart of the college campus than they were to choose a spacious yet generic office on the outskirts of campus (Biemiller, 2008). The Chronicle of Higher Education's "Great Colleges To Work For" annual survey also found that satisfaction with the physical workplace was a "key factor" in a college's selection for inclusion in their rankings (Fischmann \& Pokross, 2012), correlating positively with levels of job satisfaction. Biemiller cites the campus architect from Washington and Lee University (an ACS institution) who stated that on a college campus "people are attracted to spaces that capture the sense of being on the campus, being part of the community...They want a sense of ownership," (p. B13). This supports the current study's finding that the factor "responsibility" and its underlying constructs are important to the job satisfaction levels of employees in higher education.

Johnsrud (2000) discusses how midlevel managers - many of whom are exempt, fulltime, professional employees - are charged with the responsibility of enforcing institutional policies while often lacking the ability to influence those policies. Giving mid-level managers more of a voice in the way policies are created and implemented would increase their sense of responsibility within the institution and, according to the results of this study, increase their levels of job satisfaction.

The predictor with the second highest Beta value in the current study was "work itself" $(\beta=.23, p<.001)$. This Beta value suggests that if we could increase "work 
itself" scores by one standard deviation $(S D=.74)$, overall job satisfaction scores would be likely to increase by .23. Smerek and Peterson's study (2007) also found "work itself" to be a significant predictor of job satisfaction $(\beta=.36, p<.001)$, as did Malik (2011) in his study of faculty in higher education.

These results suggest that employee job satisfaction is tied to the content of their work and how they believe they perform their job related tasks. To increase employee scores in this area and improve overall job satisfaction scores, institutional leaders should continue to educate their employees about how their individual work makes a difference in the fulfillment of the overall mission of the institution and to emphasize to those employees that their work matters. Providing opportunities for employees to see the results of their work and therefore experience a sense of accomplishment is also important for increasing performance in this area. This may mean ensuring that leaders help employees "close the loop" and see how their work at the beginning or in the middle of a project helps to fulfill it in the end. This type of practice could increase employee levels of intrinsic motivation - motivation derived from the "work itself" rather than any external aspect. Volkwein and Zhou (2003), in a study of the job satisfaction levels of university employees, found that satisfaction with one's work - intrinsic satisfaction contributed most to levels of job satisfaction. Providing employees with a diverse array of opportunities and types of work will help to keep the job interesting and increase levels of employee engagement. Efforts of this nature will contribute to individuals enjoying their work, which is critical for maintaining high scores on the "work itself" construct which plays a significant role in overall employee job satisfaction. 
Having an effective supervisor was significantly related to job satisfaction in this study $(\beta=.21, p<.01)$. By increasing scores on the "effective supervisor" variable by one standard deviation $(S D=1.13)$, we would expect job satisfaction composite scores to increase by .21 . The qualities of an effective supervisor as measured in this survey were diverse and included ethical decision-making, the provision of constructive feedback, and the consideration of the employee's ideas - several factors that are similar to those within the construct "responsibility." It should be noted that the variable "effective supervisor" is one of Herzberg's hygiene factors, which according to his theory should have no affect on job satisfaction. The relatively high, statistically significant Beta value of this factor lends support for the acceptance of the second hypothesis in this study that stated that Herzberg's duality theory would not be validated in a higher education context.

The importance of an effective supervisor has many implications for the leadership of the four participating higher education institutions. Providing continuous training and development opportunities for all employees, including those in management positions, may make a significant difference in the overall job satisfaction levels of all employees. As discussed in this paper's literature review, Wang and Hsieh (2013) postulated that "when employees perceive that they are supported and treated sincerely, they increase their engagement at work...Winning employees' trust is a vital element of being an effective leader," (p. 614). Further, Johnsrud and Rosser (1999) found that feelings of trust and good communication with a supervisor led to higher levels of job satisfaction in mid-level staff. Rosser (2004) found that when an employee felt someone cared about their professional development and supported his or her career path, they also exhibited higher levels of job satisfaction and less intent to leave. "[T] he more positive 
midlevel leaders perceive they have been recognized and respected for their contributions to the institution, the more satisfied they become and are less likely to leave the institution," (Rosser, 2004, p. 331). Training supervisors to support their employees in this way, and teaching them how to create supportive environments are important practices that may improve employee satisfaction. The results of this study support the findings of others and suggest that supervisors with vision who can communicate well and manage people effectively may positively contribute to the overall job satisfaction levels of college employees.

The fourth highest statistically significant Beta value was for the motivator "recognition" $(\beta=.15, p<.05)$. This factor is related to the praise and recognition an employee receives from his or her supervisor, and the recognition of his or her good work by those outside the department. These results suggest that if scores on this predictor were increased by one standard deviation $(S D=1.07)$, job satisfaction scores would be expected to increase by .15 . Johnsrud (2000) articulates that recognition can take the form of "guidance, trust, communication, participation, confidence, and performance feedback," (p. 9). Research has also suggested that when employees in higher education feel recognized for their contributions to the institution, they increase their effectiveness (Lindgren, 1982). Another study found that recognition of one's competence also made a difference in the job satisfaction levels of mid-level leaders in higher education (Rosser, 2004). Institutional leadership should note that the items pertaining to this construct did not include mention of specific financial rewards or other tangible incentives, but instead referred to acts of appreciation and recognition in a more general manner. These findings are further supported by the work of Fischmann and Pokross (2012) who described 
commonalities between the environments of colleges recognized by the Chronicle of Higher Education on their annual "Great Colleges To Work For" list. Employees at those institutions listed as "Great Colleges" reported meaningful recognition programs at their schools $57 \%$ of the time, while only $44 \%$ of employees at schools not recognized with a spot on the Chronicle's list reported meaningful programs (Fischmann \& Pokross, 2012).

Johnsrud and Rosser (1999) in their discussion of what motivates mid-level staff members describe "their desire to play a supportive role in achieving their institution's mission. They want to be recognized for their expertise and participate in the planning efforts of the college or university with which they are associated," (p. 122). The results of another Johnsrud and Rosser's study found that being recognized for their competence was one of the most powerful predictors of employee morale (2000). Staff members desire to feel like their work matters ("work itself") and for their efforts to be acknowledged ("recognition"). Campus leaders should work with their employees to help them make connections between their work efforts and improvements at the institution. As a long-time senior administrator from a liberal arts college articulated, "professional satisfaction is sometimes delayed for people in [my] position, since [we] are often involved in expansive projects that don't come to fruition right away," (June, 2013, p. A40). Employers should seek ways to help employees understand the importance of their individual roles to the larger institution's success. The results from the focus of this research suggest that finding ways to improve recognition efforts may increase the job satisfaction levels of institutional employees. 
An unexpected result from this study was the statistically significant negative Beta value for the predictor "presence of core values" $(\beta=-.13, p<.05)$. This suggests that if we were to decrease scores on this predictor by one standard deviation $(S D=.90)$, we would increase job satisfaction scores by .13. These findings suggest that employees may experience higher levels of job satisfaction in an environment less structured by institutionalized values, perhaps giving them more flexibility in decision-making and within the approaches they take with their work. Incongruence between an individual's personal values and those of the institution may lead to lower levels of job satisfaction in line with the negative Beta value for this factor. Joseph Simplico (2010) articulates that the individual employees of a college or university are those who fulfill the institution's values - they are the "guardians" of a campus's culture and values. If an individual has personal values that conflict with the institution's values, or feels that the institutional values may be preventing the school from moving forward, this may cause conflict and result in lower levels of job satisfaction associated with the presence of core values. Volkwein and Parmley (2000) found that overly controlled work environments and workplace pressure contribute to lower job satisfaction scores. The presence of core institutional values, especially values that are incongruent with personal values, may increase a sense of institutional control or pressure and negatively affect job satisfaction.

In contrast to the findings of Smerek and Peterson (2007), employee ages, satisfaction with salary, effective senior management, and opportunities for advancement were not significant predictors in this study. However, the results of this study do align with the conclusions of Smerek and Peterson who determined that Herzberg's duality theory was not validated in a higher education context as both motivator and hygiene 
factors were found to significantly contribute to employee levels of job satisfaction. These results support the second hypothesis of this study.

The first hypothesis of this study was also supported by the results of the data analysis. The first hypothesis stated that the group of motivators would be a statistically significant predictor of job satisfaction of fulltime exempt professional employees in a higher education setting. Based on the results of the hierarchical linear regression which indicate that a significant amount of the variance in job satisfaction can be explained by the addition of motivators to the factor groups of personal characteristics and work characteristics, the first hypothesis is supported. As explained in the literature review of this paper, higher levels of job satisfaction have been linked to increased efficiency and a more positive workplace environment.

\section{Implications for Practice}

The results of this research have clear implications for institutional leaders in higher education. Job satisfaction has been linked to higher levels of employee performance and is known to support a more productive work environment (Johnsrud, 2002; Szekeres, 2006). Coupled with the high cost of turnover and limited resources, today's managers need to focus on those aspects of the job environment that will contribute most to higher levels of employee job satisfaction. Managers and department directors must be trained and supported in ways that make them most effective in their supervision of their employees. Employers must also seek ways to enrich the work itself, by creating opportunities for employees to voice their opinions and control their work, and to know that their work matters. Allowing employees to explore new opportunities in their current positions through committee work, continuous education, and advising 
may help to enrich the work itself while also increasing an employee's sense of responsibility. Creating workspaces closely connected to the heart and mission of a campus, even if they are not new or spacious, may also positively contribute to a positive work environment. Reinforcing the connection of employee work to the fulfillment of the institution's mission and recognizing employees for their contributions to success are important.

Many of the suggestions for employers in this paper would cost very little in terms of actual dollars, but would require great levels of time, intention, flexibility, support, and freedom. As institutions seek to be more nimble and more effective with their existing resources, these may be welcome costs that yield a significantly positive result.

Recommendations for Future Research

The results of this study, while significant, leave open several possibilities for future research. The successful implementation of a model to measure job satisfaction levels of employees in higher education should be replicated with samples from other populations. Smerek and Peterson (2007) conducted their study with business officers from a large public university while this study's sample was from liberal arts institutions within the ACS. Future research could use this study's methodology to examine the factors that most contribute to job satisfaction levels of employees in different geographic regions of the United States and to examine differences between types of institutions, and, even more granular, to examine job satisfaction differences between offices within a large university. 
The differences in mean levels of job satisfaction between employees who selfidentified as being in a racial or ethnic minority and those who did not warrants further study. Though "minority status" was not a statistically significant predictor of job satisfaction in this study, the sizable difference between means suggests that further research is necessary.

This study focused only on fulltime exempt professional staff, leaving aside those employees who make an hourly wage and/or work part time for an institution of higher education. There is an opportunity for this model to be tested within both of these populations in an effort to provide institutional leadership with information to help increase job satisfaction levels of all employees.

On a more macro level, research could be conducted to study the overall job satisfaction level of higher education employees according to Carnegie class to see if the size and focus of an institution has an overarching effect on employee levels of job satisfaction. Using the large membership lists of professional organizations such as ACPA and NASPA could potentially engage a large sample of employees in higher education for this purpose.

\section{Conclusions}

The job satisfaction levels of fulltime professional exempt employees in higher education matter; not only have higher levels of job satisfaction been connected to higher levels of efficiency and effectiveness, increases in job satisfaction have been linked to more positive work environments, improved campus culture, higher employee retention and ultimately with institutions identified as "Great Places to Work For." The 
importance of job satisfaction in the higher education environment and was the impetus for this examination of Herzberg's duality theory of motivation.

The fulltime exempt professional employees from the four institutions that participated in this study were generally satisfied with their jobs. Differences in job satisfaction levels were unrelated to either personal or work characteristics. However, several factors identified as either "motivators" or "hygiene factors" in Herzberg's model did account for significant amounts of variance within employee levels of job satisfaction. This suggests that Herzberg's theory of job satisfaction is not supported in a higher education context as, specifically, hygiene factors correlated with levels of employee job satisfaction.

This study contributes to the literature on job satisfaction in important ways, identifying those factors accounting for the greatest amount of variability in levels of job satisfaction in higher education employees. The results of this study suggest there are opportunities for institutional leadership to improve employee levels of job satisfaction and thereby enhance the performance of the institution as a whole. By identifying new ways to give employees responsibility for their work, opportunities to create interest in the work itself, by training supervisors to be more effective, delegating responsibility to employees, and maintaining inclusive core values, today's leaders in higher education have the opportunity to make a positive difference in the work lives of their employees. It is important to note the absence of salary from the five significant factors from this model. Though we may often consider money to be the driver of behavior in the workplace, this study suggests that there are avenues through which employers may enhance job satisfaction in the workplace without allocating more funding to salary and 
benefits. Though opportunities for future research exist, the results of this study should be encouraging to today's institutional leadership and provide them with a clear road map for improving employee levels of job satisfaction in the workplace. 


\section{REFERENCES}

Agresto, J. (2011). The liberal arts bubble. Academic Questions, 24(4), 392-402.

The Almanac of Higher Education. (2009, August 24). The Chronicle of Higher Education. Retrieved from http://chronicle.com/article/Employees-in-Collegesand/47995/

America's top colleges. (2012). Forbes. Retrieved from http://www.forbes.com/topcolleges/list/

Associated Colleges of the South. (n.d.) Retrieved April 21, 2014 from the ACS website: https://www.colleges.org

Association of American Colleges \& Universities (AAC\&U). (2002). Greater expectations: A new vision for learning as a nation goes to college. Retrieved from http://www.greaterexpectations.org

Bamundo, P., \& Kopelman, R. (1980). The moderating effects of occupation, age and urbanization on the relationship between job satisfaction and life satisfaction. Journal of Vocational Behavior, 17, 100-123.

Barden, D. (2005). The age of reason. Chronicle of Higher Education, 52(13), 2-3.

Barker, K. (1993). Changing assumptions and contingent solutions: The costs and benefits of women working full- and part-time. Sex Roles, 28, 47-71.

Best southern colleges 2012. (2012). Forbes. Retrieved from http://www.forbes.com/sites/specialfeatures/2012/08/01/best-southerncolleges2012/

Biemiller, L. (2008, July 18). To college employees, the work environment is allimportant. Chronicle of Higher Education, 54(45), B12-B17.

Bozeman, B., \& M. Gaughan. (2011). Job satisfaction among university faculty: Individual, work, and institutional determinants. The Journal of Higher Education, 82, 154-186.

Brown, D., \& Sargent, M. (2007). Job satisfaction, organizational commitment, and religious commitment of fulltime university employees. Journal of Research on Christian Education, 16, 211-214. 
College Board. (2012). Composition of FTE staff over time. Retrieved from:

http://trends.collegeboard.org/college-pricing/figures-tables/composition-fte-staffover-time

The Chronicle of Higher Education. (2014, March 21). [Graph illustration of 2004 freshman cohort graduation rates]. College Completion: Who graduates from college, who doesn't, and why it matters. Retrieved from: http://collegecompletion.chronicle.com/

Cook, C., Heath, F., \& Thompson, R. (2000). A meta-analysis of response rates in webor internet-based surveys. Educational and Psychological Measurement, 60, 821836.

Cowan, K. (2013). Higher education's higher accountability. The Presidency, Winter 2014. Retrieved April 1, 2014 from http://www.acenet.edu/thepresidency/columns-and-features/Pages/Higher-Education's-HigherAccountability.aspx

Curtis, J., \& Thornton, S. (2014). Losing focus: The annual report on the economic status of the profession, 2013-14. Academe, 100(2), 4-17.

de Vaus, D. (2014). Surveys in social research. New York, NY: Routledge.

Del Rey, E., \& Romero, L. (2004). Competition between public and private universities: Quality, prices, and exams. Economics Working Paper we046423, Universidad Carlos III, Departamento de Economía.

Dennison, G. (2011). Faculty workload: An analytical approach. Innovative Higher Education, 37, 297-305.

Desrochers, D., \& Kirshstein, R. (2014). Labor intensive or labor expensive? Changing staffing and compensation patterns in higher education. Washington, DC: Delta Cost Project.

Diamond, L., \& Schneider, C. (2012). Emory scandal: Critics doubt college ratings. The Atlanta Journal-Constitution. Retrieved from:

http://www.ajc.com/news/news/local/emory-scandal-critics-doubt-collegeratings/nRMSY/

Dillman, D., Smyth, J., \& Christian, L. (2009). Internet, mail, and mixed-mode surveys: The tailored design method. Hoboken, NJ: Wiley.

Eberhardt, B., \& Shani, A. (1984). The effects of full-time versus part-time employment status on attitudes toward specific organizational characteristics and overall job satisfaction. Academy of Management Journal, 27, 893-900. 
Eleswed, M., \& Mohammed, F. (2013). The impact of gender, age, years of experience, education level, and position type on job satisfaction and organizational commitment: An exploratory study in the kingdom of Bahrain. International Journal of Business and Social Science, (4)11, 108-119.

Elliott, K., \& Healy, M. (2001). Key factors influencing student satisfaction related to recruitment and retention. Journal of Marketing for Higher Education, 10(4), 111.

Ewen, R., Smith, P., Hulin, C., \& Locke, E. (1966) An empirical test of the Herzberg two-factor theory. Journal of Applied Psychology, 50, 44-50.

Fischmann, J. \& Pokross, B. (2012). At great colleges, respect is a crucial benefit. Chronicle of Higher Education, 58(43), A4.

Florenthal, B., Tolstikov-Mast, Y., \& Yilmazsoy, N. (2009). Understanding organizational culture from multiple perspectives: Faculty-staff relations analysis. The Journal of Academic Adminstration, 5(1), 29-41.

Florenthal, B., \& Tolstikov-Mast, Y. (2012). Organizational culture: Comparing faculty and staff perspectives. Journal of Higher Education Theory and Practice, 12(6), $81-90$.

Fuller, J., Hester, K., Barnett, T., Frey, L., \& Relyea, C. (2006). Perceived organizational support and perceived external prestige: Predicting organizational attachment for university faculty, staff, and administrators. The Journal of Social Psychology, 146(3), 327-347.

Gibson, J., \& Klein, S. (1970). Employee attitudes as a function of age and length of service: A re-conceptualisation. Academy of Management Journal, 13, 411-25.

Glick, L. (1992). Job satisfaction among academic administrators. Research in Higher Education, 33, 625-639.

Graen, G. \& Hulin, C. (1968) Addendum to "an empirical investigation of two implications of the two-factor theory of job satisfaction." Journal of Applied Psychology, 52, 341-342.

Green, S. (1991). How many subjects does it take to do a regression analysis? Multivariate Behavioral Research, 26, 499-510.

Hagedorn, L. (1994). Retirement proximity's role in the prediction of satisfaction in academe. Research in Higher Education, 35, 711-728. 
Herzberg, F. (1987). One more time: How do you motivate employees? Harvard Business Review 65(5), 5-16.

Herzberg, F., Mausner, B, \& Snyderman, B. (1959). The motivation to work. New York: Wiley.

Hinrichs, J., \& Mischkind, L. (1967). Empirical and theoretical limitations of the twofactor hypothesis of job satisfaction. Journal of Applied Psychology, 51, 191-200.

Holland, R., Smith, A., Hasselback, J., \& Payne, B. (2010). Survey responses: Mail versus email solicitations. Journal of Business \& Economics Research, 8(4), 9598.

Hoppock, R. (1935). Job satisfaction. New York: National Occupational Conference, Harper.

Houston, D., Meyer, L., \& Paewai, S. (2006). Academic staff workloads and job satisfaction: Expectations and values in academe. Journal of Higher Education Policy and Management, 28(1), 17-30.

Humphreys, D., \& Kelly, P. (2014). How liberal arts and sciences majors fare in employment: A report on earnings and long-term career paths. Washington, DC: Association of American Colleges and Universities.

Johnsrud, L. (2002). Measuring the quality of faculty and administrative worklife: Implications for college and university campuses. Research in Higher Education, 43, 379-395.

Johnsrud, L., \& Edwards, R. (2001, November). Mediating the intent to leave: The affective responses of midlevel administrators to their worklives. ASHE Annual Meeting Paper, Richmond, VA.

Johnsrud, L., Heck, R., \& Rosser, V. (2000). Morale matters: Midlevel administrators and their intent to leave. The Journal of Higher Education, 71, 34-59.

Johnsrud, L., \& Rosser, V. (1997). Administrative staff turnover: Predicting the intentions of stayers and leavers. Paper presented at the annual meeting of the Association for the Study of Higher Education. (ERIC Document Reproduction Service No. ED 421 936).

Johnsrud, L., \& Rosser, V. (1999). College and university midlevel administrators: Explaining and improving their morale. The Review of Higher Education, 22, 121-141.

June, A. (2013). Administrators measure their success quietly. Chronicle of Higher Education, 59(43), A40-A41. 
Kalleberg, A. (1977). Work values and job rewards: A theory of job satisfaction. American Sociological Review, 42(1), 124-143.

Kallison, J., \& Cohen, P. (2010). A new compact for higher education: Funding and autonomy for reform and accountability. Innovative Higher Education 35, 37-49.

Kezar, A. (2004). Obtaining integrity? Reviewing and examining the charter between higher education and society. Review of Higher Education, 27, 429-459.

King, N. (1970). Clarification and evaluation of the two-factor theory of job satisfaction. Psychological Bulletin, 74(1), 18-31.

Koblik, S. (2000). Foreword. In S. Koblik and S. Graubard (Eds.), Distinctively American: The residential liberal arts colleges (xv-xvi). New Brunswick, NJ: Transaction Publishers.

Krausz, M., Sagie, A., \& Bidermann, Y. (2000). Actual and preferred work schedules and scheduling control as determinants of job-related attitudes. Journal of Vocational Behavior, 56, 1-11.

Kuh, G. (2009). What student affairs professionals need to know about student engagement. Journal of College Student Development, 50, 683-706.

Kusku, F. (2003). Employee satisfaction in higher education: The case of academic and administrative staff in Turkey. Career Development International, 8(7), 347-356.

Landrum, E. (2009). Are there instructional differences between fulltime and part-time faculty? College Teaching, 57(1), 23-26.

Lefkowitz, J. (1994) Sex-related differences in job attitudes and dispositional variables: Now you see them,... Academy of Management Journal, 37(2), 323-349.

Levanoni, E., \& Sales, C. A. (1990). Differences in job attitudes between full-time and part-time Canadian employees. Journal of Social Psychology, 130, 231-237.

Liftig, R. (2014). The American adjunct: Almost always a bridesmaid, almost never a bride. Journal of College Science Teaching, 43(3), 10-11.

Lindgren, H. (1982). Leadership, authority, and power sharing. Malabar, FL: Robert E. Krieger Publishing.

Locke, E. (1968, September). What is job satisfaction? Speech presented at the meeting of the American Psychological Association, San Francisco, CA. 
Locke, E., Fitzpatrick, W., \& White, F. (1983) Job satisfaction and role clarity among university and college faculty. Review of Higher Education, 6, 343-365

Logan, N., O'Reilly, C., III, \& Roberts, K. (1973). Job satisfaction among part-time and full-time employees. Journal of Vocational Behavior, 3, 33-41.

McLendon, M., Hearn, J., \& Mokher, C. (2009). Partisans, professionals, and power: The role of political factors in state higher education funding. The Journal of Higher Education, 80, 686-713.

McPeake, J., Bateson, M., \& O'Neill, A. (2014). Electronic surveys: How to maximise success. Nurse Researcher, 21(3), 24-26.

Malik, N. (2011). Study on job satisfaction factors of faculty members at university of Balochistan. International Journal of Academic Research, 3(1), 267-272.

Marston, S., \& Brunetti, G. (2009). Job satisfaction of experienced professors at a liberal arts college. Education, 130, 323-347.

Maurer, T., \& Pierce, H. (1998). A comparison of Likert scale and traditional measures of self efficacy. Journal of Applied Psychology, 83(2), 324-329.

Miles, E., Patrick, S., \& King, W. (1996). Job level as a systemic variable in predicting the relationship between supervisory communication and job satisfaction. Journal of Occupational and Organisational Psychology, 69(3), 277-92.

Miller, D., \& Slocombe, T. (2012). Preparing students for the new reality. College Student Journal, 46(1), 18-25.

Miller, H., \& Terborg, J. (1979). Job attitudes of part-time and full-time employees. Journal of Applied Psychology, 64, 380-386.

National liberal arts college rankings. (2012). U.S. News and World Report. Retrieved From http://colleges.usnews.rankingsandreviews.com/bestcolleges/ rankings/national-liberal-arts-colleges

Nishii, L., Raver, J., \& Dominguez, A. (2000). Results of the Maryland libraries' organizational culture and diversity assessment. University of Maryland, Industrial/Organizational Psychology Program. Report available at http://www.lib.umd.edu/PUB/diversity.html.

Oshagbemi, T. (2003). Personal correlates of job satisfaction: Empirical evidence from UK universities. International Journal of Social Economics, 30(12), 1210-1232. 
Pascarella, E., Woniak, G., Seifert, T., Cruce, T., \& Blaich, C. (2005). Liberal arts colleges and liberal arts education: New evidence on impacts. ASHE Higher Education Report, 31(3).

Pedhazur, E. (1997). Multiple regression in behavioral research: Explanation and prediction ( $3^{\text {rd }}$ Ed.). Ft. Worth, TX: Harcourt Brace.

Peters, L., Jackofsky, E., \& Salter, J. (1981). Predicting turnover: A comparison of parttime and full-time employees. Journal of Occupational Behaviour, 2, 89-98.

Rampell, C. (2013, May 4). College graduates fare well in jobs market, even through recession. The New York Times, p. B1.

Rhoades, G. (2005). Capitalism, academic styles, and shared governance. Academe, 91 (3), 38-42.

Robbins, S. (1998). Organizational behavior: Concepts, controversies, applications. Upper Saddle River, NJ: Prentice Hall.

Ronen, S. (1978). Job satisfaction and the neglected variable of job seniority. Human Relations, 31, 297-308.

Rosser, V. (2000). Midlevel administrators: What we know. New Directions for Higher Education, 111, 5-13.

Rosser, V. (2004). A national study on midlevel leaders in higher education: The unsung professionals of the academy. Higher Education, 48, 317-337.

Rosser, V., \& Javinar, J. (2003). Midlevel student affairs leaders' intentions to leave: Examining the quality of their professional and institutional work life. Journal of College Student Development, 44, 813-830.

Ryan, R., \& Deci, E. (2000). Intrinsic and extrinsic motivations: Classic definitions and new directions. Contemporary Educational Psychology, 25, 54-67. doi:10.1006/ceps.1999.1020

Ryan, J., Healy, R., \& Sullivan, J. (2012). Oh, won't you stay? Predictors of faculty intent to leave a public research university. Higher Education, 63, 421-437.

Scott, R. (1978). Lords, squires, and yeoman: Collegiate middle managers and their organizations. ASHE-ERIC/Higher Education Research Report, No. 7. Washington, DC: American Association for Higher Education.

Seifert, T., Goodman, K., Lindsay, N., Jorgensen, J., Wolniak, G., Pascarella, E., \& Blaich, C. (2008). The effects of liberal arts experiences on liberal arts outcomes. Research in Higher Education, 49, 107-125. 
Shockey, M., \& Mueller, C. (1994). At-entry differences in part-time and full-time employees. Journal of Business and Psychology, 8, 355-364.

Siassi, I., Crocetti, G., \& Spiro, H. (1975). Emotional health, life and job satisfaction in ageing workers. Industrial Gerontology, 2, 289-96.

Simplicio, J. (2010). Portrait of the college employee: Work 'em to death, or just leave 'em alone. Education, 131(1), 135-138.

Simplicio, J. (2012). The university culture. Education, 133(2), 336-339.

Sinclair, R., Martin, J., \& Michel, R. (1999). Full-time and part-time subgroup differences in job attitudes and demographic characteristics. Journal of Vocational Behavior, 55, 337-357.

Smerek, R., \& Peterson, M. (2007). Examining Herzberg's theory: Improving job satisfaction among non-academic employees at a university. Research in Higher Education, 48, 229-250.

Smith, D., Tovar, E., \& Garcia, H. (2012). Where are they? A multilens examination of the distribution of fulltime faculty by institutional type, race/ethnicity, gender, and citizenship. New Directions for Institutional Research, 155, 5-26.

Steffy, B., \& Jones, J. (1990). Differences between full-time and part-time employees in perceived role strain and work satisfaction. Journal of Organizational Behavior, $11,321-329$.

Szekeres, J. (2006). General staff experiences in the corporate university. Journal of Higher Education Policy and Management, 28(2), 133-145.

Tandberg, D. (2010). Politics, interest groups and state funding of public higher education. Research in Higher Education, 51, 416-450.

Thorsteinston, T. (2003). Job attitudes of part-time vs. full-time workers: A meta-analytic review. Journal of Occupational and Organizational Psychology, 76, 151-177.

Tierney, W. (2011). Too big to fail: The role of for-profit colleges and universities in American higher education. Change, 43(6), 27-32.

Tu, L. Plaisent, M., Prosper, B., \& Lassana, M. (2005). Comparative age differences of job satisfaction on faculty at higher education level: China and Taiwan. The International Journal of Educational Management 19(2/3), 259-267. 
U.S. Department of Education, National Center for Education Statistics, Education Directory, Higher Education, 1969-70 through 1974-75; Education Directory, Colleges and Universities, 1975-76 through 1985-86; 1982-83 Supplement to the Education Directory, Colleges and Universities; and 1986-87 through 2009-10 Integrated Postsecondary Education Data System, "Institutional Characteristics Survey" (IPEDS-IC:86-99), and Spring 2000 through Spring 2010. Retrieved from: http://nces.ed.gov/pubs2011/2011015_3a.pdf

U.S. Department of Education, National Center for Education Statistics. (2012). Digest of Education Statistics, 2011 (NCES 2012-001), Chapter 3.

U.S. Department of Education, National Center for Education Statistics, Integrated Postsecondary Education Data System (IPEDS). (2009). Human resources component, employees by assigned position section. Retrieved from: http://nces.ed.gov/datalab/tableslibrary/viewtable.aspx?tableid=7078

Van Vaught, F. (2008). Mission diversity and reputation in higher education. Higher Education Policy, 21(2), 151-174.

Volkwein, J., \& Parmley, K. (2000). Comparing administrative satisfaction in public and private universities. Research in Higher Education, 41, 95-116.

Volkwein, J., \& Zhou, Y. (2003). Testing a model of administrative job satisfaction. Research in Higher Education, 44, 149-171.

Waltman, J., Bergom, I., Hollenshead, C., Miller, J. (2012). Factors contributing to job satisfaction and dissatisfaction among non-tenure-track faculty. The Journal of Higher Education, 83, 411-434.

Wagoner, R. (2007). Part-time faculty satisfaction across missions and disciplines. New Directions for Community Colleges, 140, 75-81.

Wang, D. \& Hsieh, C. (2013). The effect of authentic leadership on employee trust and employee engagement. Social Behavior and Personality, 41(4), 613-624.

Warr, P. (1992). Age and occupational well-being. Psychology and Aging, 7(1), 37-45.

Wesbrook, S. (1980, Spring). Morale, proficiency, and discipline. Journal of Political and Military Sociology, 8(1), 43-54.

Wharton, A., Rotolo, T., \& Bird, S. (2000). Social context at work: A multilevel analysis of job satisfaction. Sociological Forum, 15, 65-90.

Whitchurch, C. (2007). The changing roles and identities of professional managers in UK higher education. Perspectives, 11(2), 53-60. 
Wood, O. (1976). A research project: Measuring job satisfaction of the community college staff. Community College Review, 3(3), 56-64.

Wotruba, T. (1990). Full-time versus part-time salespeople: A comparison on job satisfaction, performance, and turnover in direct selling. International Journal of Research in Marketing, 7, 97-108. 


\section{APPENDIX A}

\section{Survey Instrument}

Consent to Participate in a Research Study: Staff Survey on Workplace Climate at Sewanee: The University of the South

You are invited to participate in a research study about the climate of your workplace.

If you agree to be part of the research study, you will be asked to complete an online survey.

The survey will ask you to provide brief demographic information about yourself, demographic information regarding your workplace, and other details regarding the factors that affect your work. This research will be conducted with fulltime staff employees at your institution and other institutions of higher education within the Associated Colleges of the South consortium. Each institution will receive an aggregated, anonymous report of employee responses to improve understanding of the effect of various factors on the workplace climate.

There is little to no harm inherent in the study's design and purpose, although unforeseen risks may occur. Some participants may experience discomfort in answering survey questions if they consider the information to be threatening or sensitive. However, participants do not have to answer any question they do not want to answer. The survey should take less than twenty minutes to complete. Survey participants will not be compensated for their participation in this study. Participating in this study is completely voluntary. Even if you decide to participate now, you may change your mind and stop at any time. You may choose not to answer any of the survey questions, or cease your participation at any time or for any reason. The most valuable information will be collected from complete surveys. If you have questions about this research study, you may contact Patrick Noltemeyer, jpnolt01@louisville.edu, Principal Investigator, or Dr. Amy Hirschy, amy.hirschy@louisville.edu, Faculty Advisor. The University of Louisville Institutional Review Board has approved this study.

Are you willing to participate in this study by completing an online survey?

$$
\text { Yes }
$$

$$
\text { No }
$$

If No Is Selected, Then Skip To End of Survey 
For the following questions, please use the scale below.

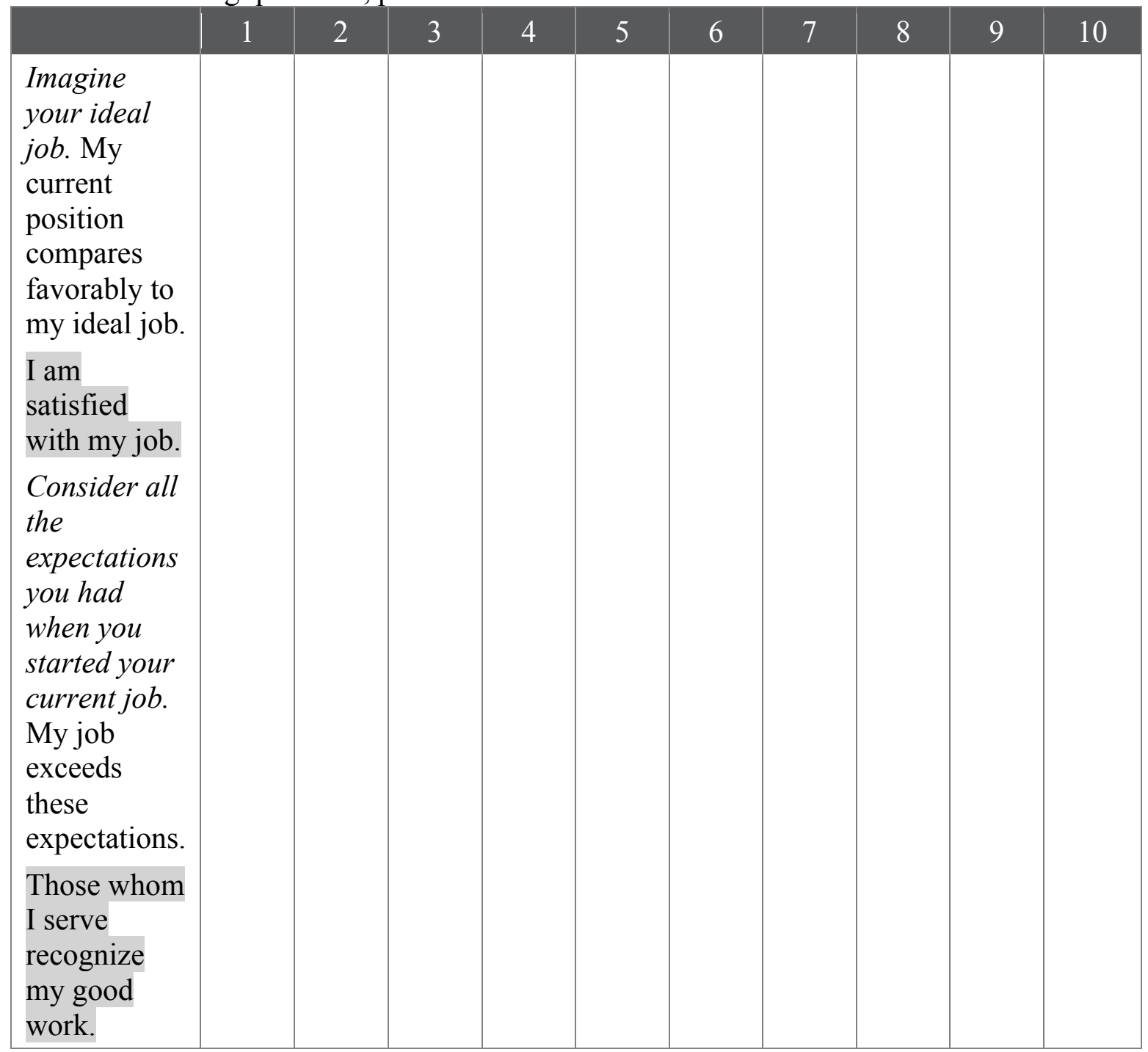


For the following questions, please use the scale below.

\begin{tabular}{|c|c|c|c|c|c|c|c|c|c|c|}
\hline & 1 & 2 & 3 & 4 & 5 & 6 & 7 & 8 & 9 & 10 \\
\hline $\begin{array}{l}\text { My } \\
\text { contributions } \\
\text { are valued by } \\
\text { members of the } \\
\text { institutional } \\
\text { community } \\
\text { outside of my } \\
\text { unit/department. }\end{array}$ & & & & & & & & & & \\
\hline $\begin{array}{l}\text { In the last seven } \\
\text { days I have } \\
\text { received } \\
\text { recognition or } \\
\text { praise for doing } \\
\text { good work. }\end{array}$ & & & & & & & & & & \\
\hline $\begin{array}{l}\text { I get } \\
\text { appropriate } \\
\text { recognition } \\
\text { when I have } \\
\text { done something } \\
\text { extraordinary. }\end{array}$ & & & & & & & & & & \\
\hline $\begin{array}{l}\text { Expressions of } \\
\text { thanks and } \\
\text { appreciation are } \\
\text { common in my } \\
\text { unit/department. }\end{array}$ & & & & & & & & & & \\
\hline
\end{tabular}


For the following questions, please use the scale below.

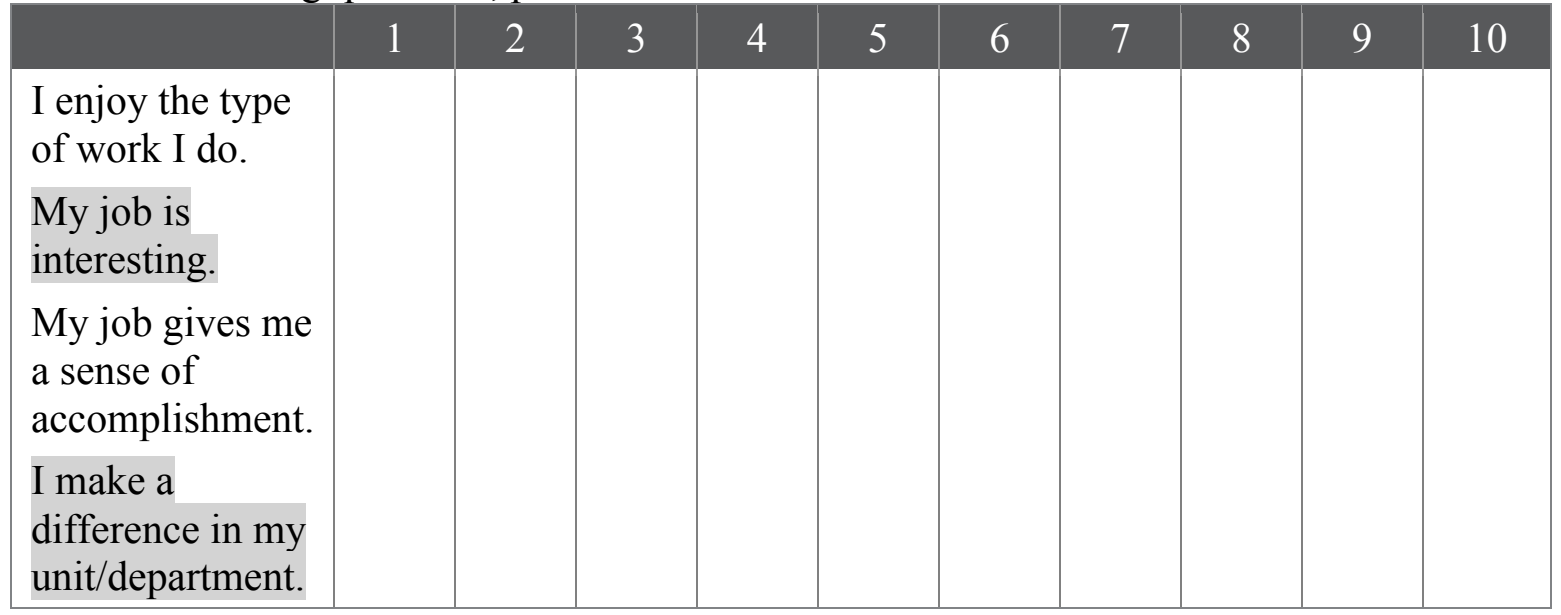


For the following questions, please use the scale below.

\begin{tabular}{|c|c|c|c|c|c|c|c|c|c|c|}
\hline & 1 & 2 & 3 & 4 & 5 & 6 & 7 & 8 & 9 & 10 \\
\hline $\begin{array}{l}\text { Opportunitie } \\
\text { for } \\
\text { advancemen } \\
\text { or promotion } \\
\text { exist within } \\
\text { the } \\
\text { institution. }\end{array}$ & & & & & & & & & & \\
\hline $\begin{array}{l}\text { I know what } \\
\text { is required o } \\
\text { me to } \\
\text { advance } \\
\text { within the } \\
\text { institution. }\end{array}$ & & & & & & & & & & \\
\hline $\begin{array}{l}\text { Internal } \\
\text { candidates } \\
\text { receive fair } \\
\text { consideration } \\
\text { for open } \\
\text { positions. }\end{array}$ & & & & & & & & & & \\
\hline $\begin{array}{l}\text { Information } \\
\text { about job } \\
\text { vacancies } \\
\text { within the } \\
\text { institution is } \\
\text { readily } \\
\text { available. }\end{array}$ & & & & & & & & & & \\
\hline
\end{tabular}


For the following questions, please use the scale below.

\begin{tabular}{|c|c|c|c|c|c|c|c|c|c|c|}
\hline & 1 & 2 & 3 & 4 & 5 & 6 & 7 & 8 & 9 & 10 \\
\hline $\begin{array}{l}\text { My } \\
\text { unit/department } \\
\text { offers the } \\
\text { training or } \\
\text { education that } \\
\text { I need to grow } \\
\text { in my job. }\end{array}$ & & & & & & & & & & \\
\hline $\begin{array}{l}\text { I have received } \\
\text { the necessary } \\
\text { training to do } \\
\text { my job well. }\end{array}$ & & & & & & & & & & \\
\hline $\begin{array}{l}\text { I have had } \\
\text { opportunities at } \\
\text { work to learn } \\
\text { and grow in the } \\
\text { past year. }\end{array}$ & & & & & & & & & & \\
\hline $\begin{array}{l}\text { There is } \\
\text { someone at } \\
\text { work who } \\
\text { encourages my } \\
\text { development. }\end{array}$ & & & & & & & & & & \\
\hline
\end{tabular}


For the following questions, please use the scale below.

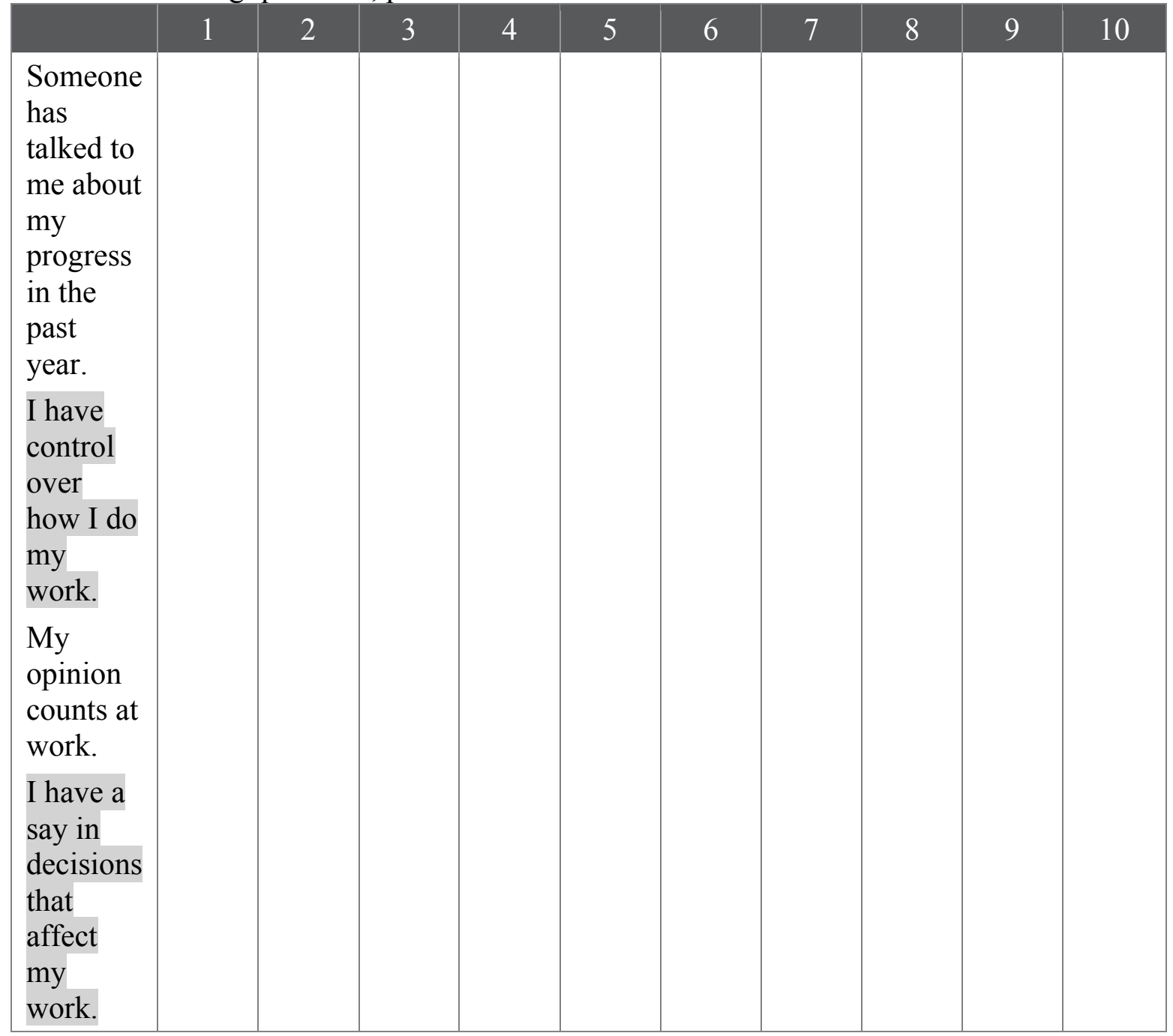


For the following questions, please use the scale below.

\begin{tabular}{|c|c|c|c|c|c|c|c|c|c|c|}
\hline & 1 & 2 & 3 & 4 & 5 & 6 & 7 & 8 & 9 & 10 \\
\hline $\begin{array}{l}\text { The } \\
\text { physical } \\
\text { environment } \\
\text { allows me } \\
\text { to do my } \\
\text { job. }\end{array}$ & & & & & & & & & & \\
\hline $\begin{array}{l}\text { I have the } \\
\text { necessary } \\
\text { resources, } \\
\text { tools, or } \\
\text { equipment } \\
\text { to do my } \\
\text { job. }\end{array}$ & & & & & & & & & & \\
\hline $\begin{array}{l}\text { I feel a } \\
\text { strong sense } \\
\text { of } \\
\text { belonging to } \\
\text { the } \\
\text { institution. }\end{array}$ & & & & & & & & & & \\
\hline $\begin{array}{l}\text { I enjoy } \\
\text { discussing } \\
\text { the } \\
\text { institution } \\
\text { with people } \\
\text { who do not } \\
\text { work here. }\end{array}$ & & & & & & & & & & \\
\hline
\end{tabular}


For the following questions, please use the scale below.

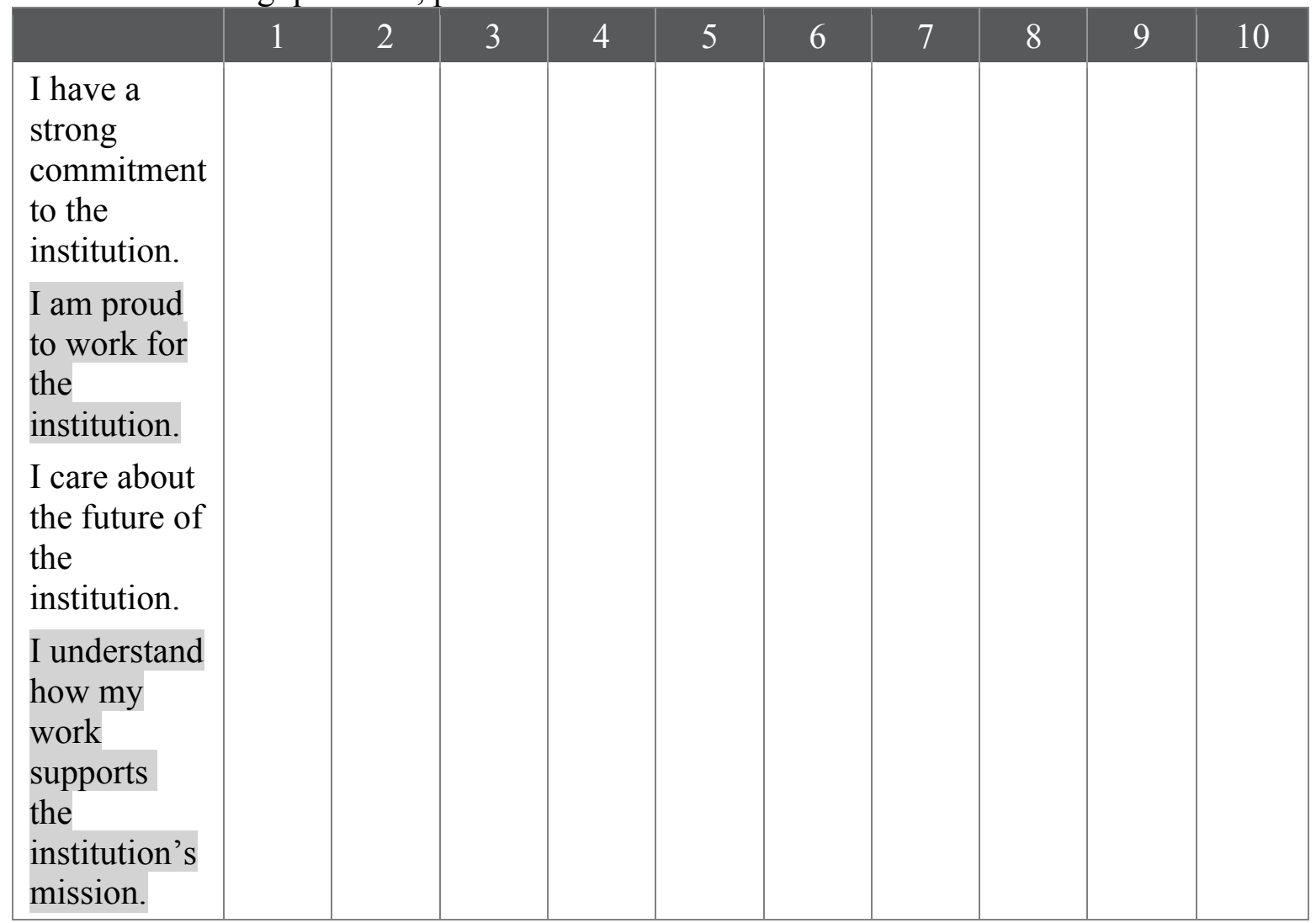


For the following questions, please use the scale below.

\begin{tabular}{|c|c|c|c|c|c|c|c|c|c|}
\hline & 1 & 2 & 3 & 4 & 5 & 6 & 7 & & 10 \\
\hline $\begin{array}{l}\text { I understand } \\
\text { how my work } \\
\text { supports the } \\
\text { mission of my } \\
\text { unit/department. }\end{array}$ & & & & & & & & & \\
\hline $\begin{array}{l}\text { I know what is } \\
\text { expected of me } \\
\text { at work. }\end{array}$ & & & & & & & & & \\
\hline $\begin{array}{l}\text { Work is } \\
\text { organized so } \\
\text { that each person } \\
\text { can see the } \\
\text { relationship } \\
\text { between his/her } \\
\text { job and the } \\
\text { goals of the } \\
\text { institution. }\end{array}$ & & & & & & & & & \\
\hline $\begin{array}{l}\text { The goals of my } \\
\text { unit/department } \\
\text { are clear to me. }\end{array}$ & & & & & & & & & \\
\hline
\end{tabular}


For the following questions, please use the scale below.

\begin{tabular}{|c|c|c|c|c|c|c|c|c|c|c|}
\hline & 1 & 2 & 3 & 4 & 5 & 6 & 7 & 8 & 9 & 10 \\
\hline $\begin{array}{l}\text { Senior } \\
\text { management } \\
\text { keeps } \\
\text { employees } \\
\text { informed. }\end{array}$ & & & & & & & & & & \\
\hline $\begin{array}{l}\text { Senior } \\
\text { management } \\
\text { effectively } \\
\text { communicates } \\
\text { the goals and } \\
\text { strategies of our } \\
\text { unit/department. }\end{array}$ & & & & & & & & & & \\
\hline $\begin{array}{l}\text { Senior } \\
\text { management } \\
\text { demonstrates } \\
\text { leadership } \\
\text { practices that } \\
\text { are consistent } \\
\text { with the stated } \\
\text { values of our } \\
\text { unit/department. }\end{array}$ & & & & & & & & & & \\
\hline $\begin{array}{l}\text { My supervisor } \\
\text { communicates } \\
\text { well. }\end{array}$ & & & & & & & & & & \\
\hline
\end{tabular}


For the following questions, please use the scale below.

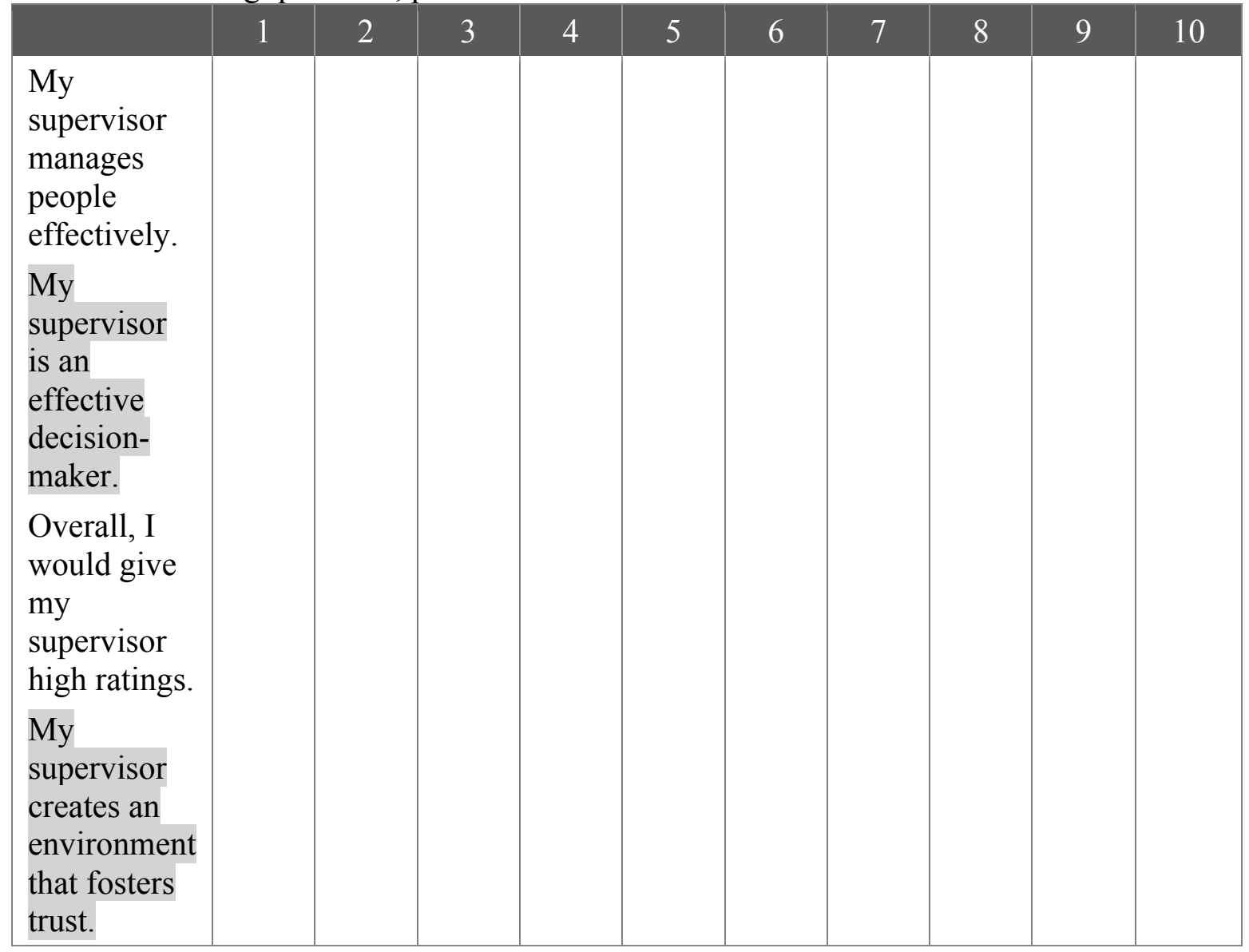


For the following questions, please use the scale below.

\begin{tabular}{|c|c|c|c|c|c|c|c|c|c|c|}
\hline & 1 & 2 & 3 & 4 & 5 & 6 & 7 & 8 & 9 & 10 \\
\hline $\begin{array}{l}\text { My } \\
\text { supervisor is } \\
\text { approachable } \\
\text { and easy to } \\
\text { talk with. } \\
\text { My } \\
\text { supervisor } \\
\text { cares about } \\
\text { me as a } \\
\text { person. } \\
\text { My } \\
\text { supervisor is } \\
\text { ethical in } \\
\text { day-to-day } \\
\text { practices. } \\
\text { My } \\
\text { supervisor } \\
\text { gives me } \\
\text { constructive } \\
\text { feedback on } \\
\text { my } \\
\text { performance. }\end{array}$ & & & & & & & & & & \\
\hline
\end{tabular}


For the following questions, please use the scale below.

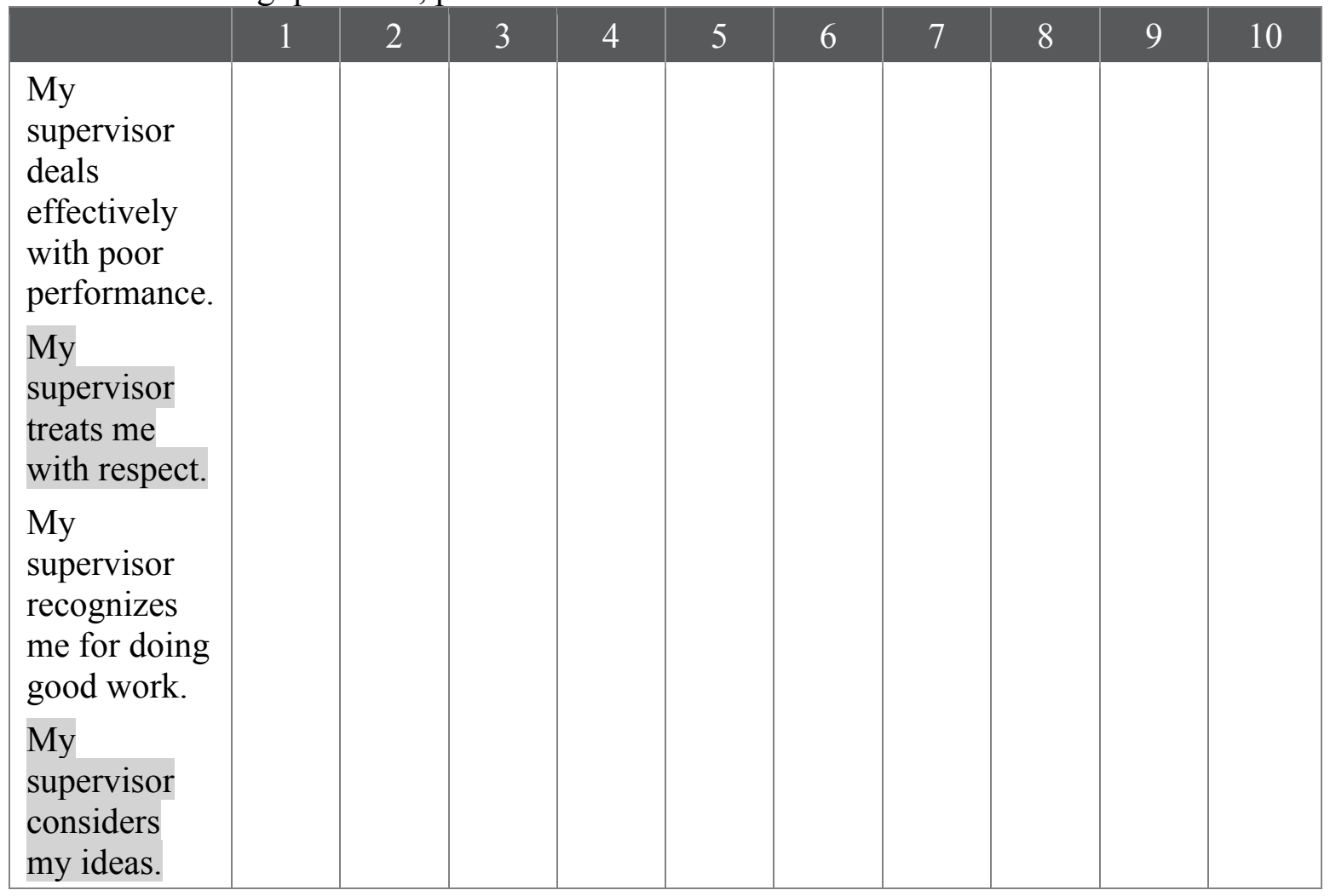


For the following questions, please use the scale below.

\begin{tabular}{|c|c|c|c|c|c|c|c|c|c|c|}
\hline & 1 & 2 & 3 & 4 & 5 & 6 & 7 & 8 & & 10 \\
\hline $\begin{array}{l}\text { My } \\
\text { supervisor } \\
\text { trusts me. } \\
\text { My } \\
\text { supervisor } \\
\text { has a clear } \\
\text { view of } \\
\text { where our } \\
\text { department } \\
\text { is going } \\
\text { and how to } \\
\text { get there. } \\
\text { I trust my } \\
\text { co-workers. } \\
\text { I am } \\
\text { consistently } \\
\text { treated with } \\
\text { respect by } \\
\text { my co- } \\
\text { workers. }\end{array}$ & & & & & & & & & & \\
\hline
\end{tabular}


For the following questions, please use the scale below.

\begin{tabular}{|c|c|c|c|c|c|c|c|c|c|c|}
\hline & 1 & 2 & 3 & 4 & 5 & 6 & 7 & $\varepsilon$ & 9 & 10 \\
\hline $\begin{array}{l}\text { I can count on } \\
\text { my co-workers } \\
\text { to help out } \\
\text { when needed. }\end{array}$ & & & & & & & & & & \\
\hline $\begin{array}{l}\text { My co-workers } \\
\text { and I work as } \\
\text { part of a team. }\end{array}$ & & & & & & & & & & \\
\hline $\begin{array}{l}\text { People care } \\
\text { about each } \\
\text { other in my } \\
\text { unit/department. }\end{array}$ & & & & & & & & & & \\
\hline $\begin{array}{l}\text { Someone in my } \\
\text { unit/department } \\
\text { cares about me } \\
\text { as a person. }\end{array}$ & & & & & & & & & & \\
\hline
\end{tabular}


For the following questions, please use the scale below.

\begin{tabular}{|c|c|c|c|c|c|c|c|c|c|c|}
\hline & 1 & 2 & 3 & 4 & 5 & 6 & 7 & 8 & 9 & 10 \\
\hline $\begin{array}{l}\text { When I joined } \\
\text { my } \\
\text { unit/department, } \\
\text { I was made to } \\
\text { feel welcome. }\end{array}$ & & & & & & & & & & \\
\hline $\begin{array}{l}\text { My workgroup } \\
\text { collaborates } \\
\text { effectively with } \\
\text { other } \\
\text { workgroups or } \\
\text { departments. }\end{array}$ & & & & & & & & & & \\
\hline $\begin{array}{l}\text { My salary/pay } \\
\text { rate is } \\
\text { competitive } \\
\text { when } \\
\text { compared to } \\
\text { similar jobs at } \\
\text { other } \\
\text { organizations. }\end{array}$ & & & & & & & & & & \\
\hline $\begin{array}{l}\text { I am paid fairly } \\
\text { for the work I } \\
\text { do. }\end{array}$ & & & & & & & & & & \\
\hline
\end{tabular}


For the following questions, please use the scale below.

\begin{tabular}{|c|c|c|c|c|c|c|c|c|c|c|}
\hline & 1 & 2 & 3 & 4 & 5 & 6 & 7 & 8 & 9 & 10 \\
\hline $\begin{array}{l}\text { Salary/pay } \\
\text { increases } \\
\text { are } \\
\text { appropriate. } \\
\text { I } \\
\text { understand } \\
\text { how my } \\
\text { base salary } \\
\text { is } \\
\text { determined. } \\
\text { My } \\
\text { salary/pay } \\
\text { rate is a } \\
\text { significant } \\
\text { factor in } \\
\text { my } \\
\text { decision to } \\
\text { stay at the } \\
\text { institution. } \\
\text { The } \\
\text { institution's } \\
\text { benefits } \\
\text { package } \\
\text { meets my } \\
\text { needs. }\end{array}$ & & & & & & & & & & \\
\hline
\end{tabular}


For the following questions, please use the scale below.

\begin{tabular}{|c|c|c|c|c|c|c|c|c|c|c|}
\hline & 1 & 2 & 3 & 4 & 5 & 6 & 7 & 8 & 9 & 10 \\
\hline $\begin{array}{l}\text { My costs } \\
\text { associated } \\
\text { with the } \\
\text { benefits } \\
\text { plan (co- } \\
\text { pays, } \\
\text { deductibles, } \\
\text { premiums) } \\
\text { are } \\
\text { reasonable. } \\
\text { The } \\
\text { benefits } \\
\text { package is } \\
\text { a } \\
\text { significant } \\
\text { factor in } \\
\text { my } \\
\text { decision to } \\
\text { stay at the } \\
\text { institution. } \\
\text { The } \\
\text { institution's } \\
\text { benefits } \\
\text { package } \\
\text { has been } \\
\text { adequately } \\
\text { explained } \\
\text { to me. }\end{array}$ & & & & & & & & & & \\
\hline
\end{tabular}


For the following questions, please use the scale below.

\begin{tabular}{|c|c|c|c|c|c|c|c|c|c|c|}
\hline & 1 & 2 & 3 & 4 & 5 & 6 & 7 & 8 & 9 & 10 \\
\hline $\begin{array}{l}\text { Ignoring my } \\
\text { unit/department's } \\
\text { core values at } \\
\text { work will get me } \\
\text { in trouble. }\end{array}$ & & & & & & & & & & \\
\hline $\begin{array}{l}\text { There is a clear } \\
\text { and consistent set } \\
\text { of values that } \\
\text { governs the way } \\
\text { we conduct our } \\
\text { work. }\end{array}$ & & & & & & & & & & \\
\hline $\begin{array}{l}\text { All } \\
\text { units/departments } \\
\text { of the institution } \\
\text { share common } \\
\text { "values. }\end{array}$ & & & & & & & & & & \\
\hline
\end{tabular}


Please identify your gender.

Male

Female

Prefer not to answer

Please identify your age.

18-24

25-29

30-34

35-39

40-44

45-49

50-54

55-59

60-64

$65+$

Are you Hispanic or Latino?

Yes

No

Prefer not to answer

Answer If "Are you Hispanic or Latino?" No Is Selected

Please select one of the following choices to best describe your race.

American Indian or Alaska Native, non-Hispanic

Asian, non-Hispanic

Black or African American, non-Hispanic

Native Hawaiian or Other Pacific Islander, non-Hispanic

Non-Resident Alien

Two or more Races, non-Hispanic

White, non-Hispanic

Prefer not to answer 
How long have you been employed by your current institution?

Less than 2 years

2-4 years

5-7 years

$8-10$ years

$11-15$ years

$16-20$ years

21-25 years

More than 25 years

Job Category (if you are unsure of your job category, click on the radio buttons below and then review the dropdown list for the job role within each category).

Administration

Exempt Professional Staff

Answer If Job Category (if you are unsure of your job category, click on the radio buttons below and then review the dropdown list for the job role within each category).

"Administration Is Selected"

From the list below, please select the one option that best describes your primary job role. Administration

Executive

Chancellor/President

Vice Chancellor/Vice President

Provost

Vice Provost

Associate/Assistant Provost

Associate Vice President

Assistant Vice President

School Director

Administrator

Director

Associate Director

Assistant Director

Academic Dean

Associate Dean

Assistant Dean

Dean-Non-academic

Other 
Answer If Job Category (if you are unsure of your job category, click on the radio buttons below and then review the dropdown list for the job role within each category). "Exempt Professional" Staff Is Selected

From the list below, please select the one option that best describes your primary job role. Exempt Professional Staff

Analyst

Advisor

Counselor

Manager

Professional

Specialist

Other

What best describes the person to whom you directly report?

Provost or President

Vice President / Senior Student Affairs Officer

Assistant / Associate Vice President

Department Head / Unit Head

Assistant / Associate Director

Other 
From the drop down menu below, please select the one option that most directly captures the Department with which you are most closely associated.

Academic Affairs

Athletics

Building \& Grounds Maintenance

External Affairs - Development

External Affairs - Government \& Community Relations

External Affairs - Public Affair

Facilities Management

Finance-Accounting

Finance - Audit

Finance - Budget

Finance - Procurement

Food Services

Human Resources

Information Technology

Library Services

President's Office

Provost's Office

Public Safety / Law Enforcement

Student - Admissions

Student - Career Services

Student - Counseling

Student - Financial Aid

Student Health/Health Care

Services Student - Registrar

Student - Residence Life

Support Operations

Other

Do you have any instructional role?

Yes

No

If Yes Is Selected

How many courses do you teach each year?

Please provide the number of fulltime professional staff in your department. 
Please identify your current annual income from your institution from the following ranges.

Your responses to these items are strictly confidential. They will be used only in statistical summaries.

$\$ 25,000$ or less

$\$ 25,001$ to $\$ 50,000$

$\$ 50,001$ to $\$ 75,000$

$\$ 75,001$ to $\$ 100,000$

$\$ 100,001$ to $\$ 125,000$

$\$ 125,001$ to $\$ 150,000$

$\$ 150,001$ to $\$ 175,000$

$\$ 175,001$ or more

What is the highest degree you have completed? Do not include honorary degrees. (If you have none of the degrees or awards, select "Not applicable"

Not applicable (Do not hold a degree)

Doctoral degree (Ph.D., Ed.D., etc.)

First-professional degree (M.D., D.O., D.M.D., J.D., M.Div., etc.)

Master of Fine Arts, Master of Social Work (M.F.A., M.S.W.)

Other master's degree (M.A., M.S., M.B.A, M.Ed., etc.)

Bachelor's degree (B.A., A.B., B.S., etc.)

Associate's degree or equivalent (A.A., A.S., etc.)

Certificate or diploma for completion of undergraduate program (other than associate's or bachelor's) 


\section{APPENDIX B}

Table 3

Variables Measured in Work Climate

Survey

$$
\text { Influences on the work environment }
$$

Personal characteristics $\quad$ Measure

Age

Gender

Length of Employment

Level of Education
10 categories; " $18-25$ " to " $65+$ "

Dummy coded;

$0=$ Male

$1=$ Female

8 categories; "Less than 2 years" to

"More than 25 years"

8 categories; "Not applicable (do not

hold a degree)" to "Doctoral degree

(Ph.D., Ed.D., etc.)" 
Table 3 (cont.)

Variables Measured in Work Climate

Survey

Influences on the work environment

Personal characteristics

Measure

Dummy coded;

$0=$ Yes, $1=$ No/Did not respond

$0=$ Yes: all individuals either answered

that they were Hispanic or that they were a

race other than White, non-Hispanic;

$1=$ No: all individuals who answered that

they were not Hispanic and were White,

non-Hispanic; and all individuals who

answered that they preferred not to indicate

Minority status

their race or minority status

8 categories; $\$ 25,000$ or less” to “ $\$ 175,001$

Salary

or more" 
Table 3 (cont.)

Variables Measured in Work Climate

Survey

Work Characteristics

Measure

Dummy coded;

$0=$ Administration

Area of Employment

$1=$ Exempt professional staff

No. of Professional Staff in Department

Ratio

Perceived work environment

\begin{tabular}{ll}
\hline \multicolumn{1}{c}{ Motivator } & \multicolumn{1}{c}{ Measure } \\
\hline I understand how my work supports the & institution's mission. \\
& I understand how my work supports the \\
& mission of my unit/department. \\
& I know what is expected of me at work. \\
& Work is organized so that each person can \\
see the relationship between his/her job and & the goals of the institution.
\end{tabular}


Table 3 (cont.)

Variables Measured in Work Climate

Survey

Perceived work environment

\begin{tabular}{ll}
\hline Motivator & \multicolumn{1}{c}{ Measure } \\
\hline & I understand how my work supports the \\
& institution's mission. \\
& I understand how my work supports the \\
& mission of my unit/department. \\
& I know what is expected of me at work. \\
& Work is organized so that each person can \\
& see the relationship between his/her job and \\
& the goals of the institution. \\
The goals of my unit/department are clear & to me.
\end{tabular}


Table 3 (cont.)

Variables Measured in Work Climate

Survey

Perceived work environment

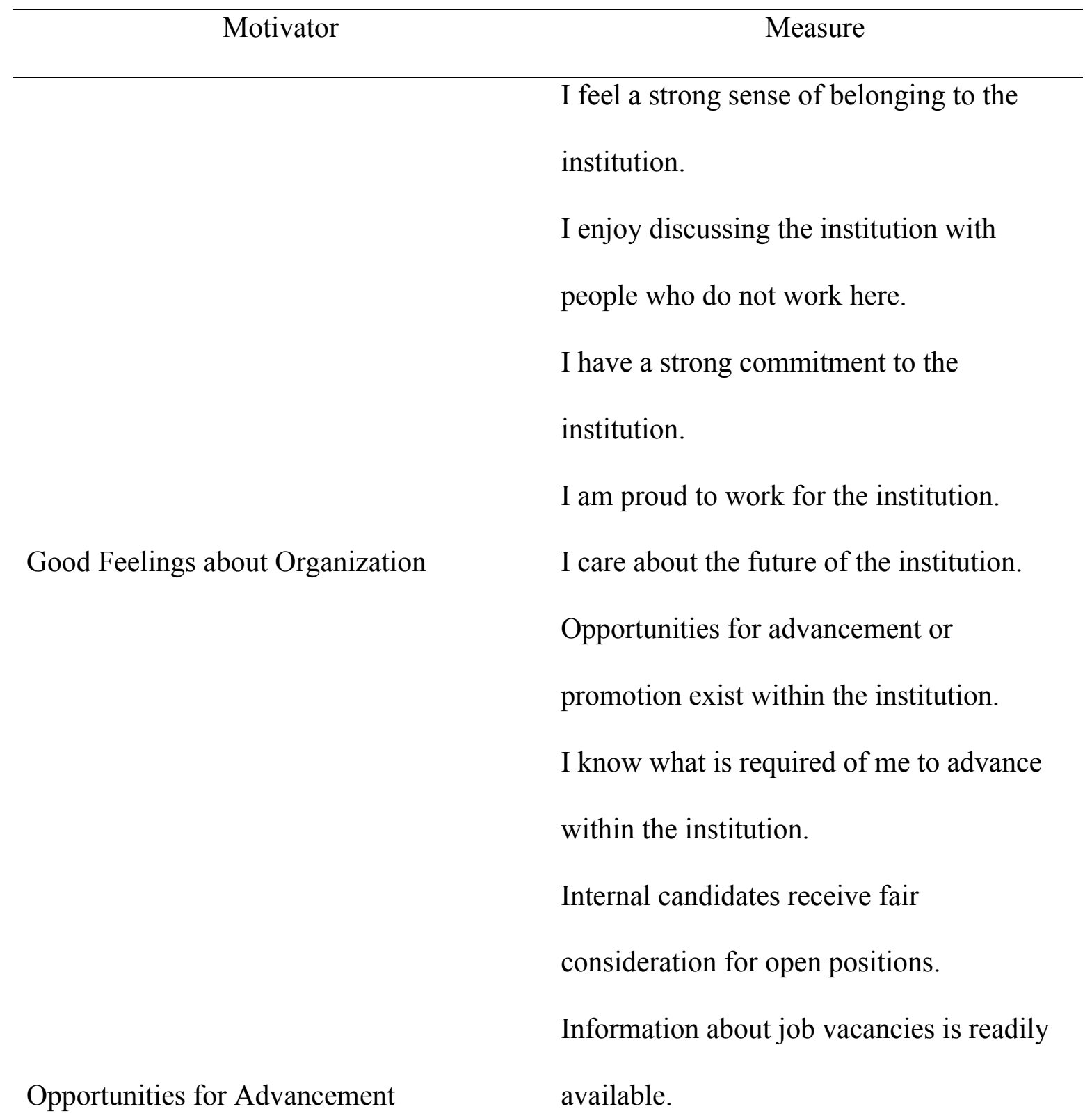


Table 3 (cont.)

Variables Measured in Work Climate

Survey

Perceived work environment

\begin{tabular}{ll}
\hline \multicolumn{1}{c}{ Motivator } & \multicolumn{1}{c}{ Measure } \\
\hline & My unit/department offers the training or \\
& education that I need to grow in my job. \\
& I have received the necessary training to do \\
& my job well. \\
& I have had opportunities at work to learn \\
and grow in the past year. & There is someone at work who encourages \\
my development. \\
Professional Growth Opportunities
\end{tabular}


Table 3 (cont.)

Variables Measured in Work Climate

Survey

Perceived work environment

\begin{tabular}{ll}
\hline \multicolumn{1}{l}{ Motivator } & \multicolumn{1}{c}{ Measure } \\
\hline & Those whom I serve recognize my good \\
& work. \\
& My contributions are valued by members \\
& of the institutional community outside of \\
& my unit/department. \\
& In the last seven days I have received \\
recognition or praise for doing good work. & \\
I get appropriate recognition when I have & done something extraordinary. \\
Recognition & Expressions of thanks and appreciation are \\
common in my unit/department.
\end{tabular}


Table 3 (cont.)

Variables Measured in Work Climate

Survey

Perceived work environment

\begin{tabular}{ll}
\hline Motivator & \multicolumn{1}{c}{ Measure } \\
\hline & I have control over how I do my work. \\
& My opinion counts at work. \\
& I have a say in decisions that affect my \\
& work. \\
& The physical environment allows me to do \\
& my job. \\
& I have the necessary resources, tools or \\
Responsibility & equipment to do my job. \\
& I enjoy the type of work I do. \\
Mork itself & My job is interesting. \\
My job gives me a sense of & accomplishment. \\
& I make a difference in my unit/department.
\end{tabular}


Table 3 (cont.)

Variables Measured in Work Climate

Survey

Perceived work environment

\begin{tabular}{|c|c|}
\hline Hygiene factor & Measure \\
\hline & Senior management keeps employees \\
\hline & informed. \\
\hline & Senior management effectively \\
\hline & communicates the goals and strategies of \\
\hline & our unit/department. \\
\hline & Senior management demonstrates \\
\hline & leadership practices that are consistent with \\
\hline \multirow[t]{10}{*}{ Effective Senior Management } & the stated values of our unit/department. \\
\hline & My supervisor communicates well. \\
\hline & My supervisor manages people effectively. \\
\hline & My supervisor is an effective decision- \\
\hline & maker. \\
\hline & Overall, I would give my supervisor high \\
\hline & ratings. \\
\hline & My supervisor creates an environment that \\
\hline & fosters trust. \\
\hline & My supervisor is approachable and easy to \\
\hline Effective Supervisor & talk with. \\
\hline
\end{tabular}


Table 3 (cont.)

Variables Measured in Work Climate

Survey

Perceived work environment

\begin{tabular}{ll}
\hline Hygiene factor & \multicolumn{1}{c}{ Measure } \\
& My supervisor cares about me as a person. \\
& My supervisor is ethical in day-to-day \\
& practices. \\
& My supervisor gives me constructive \\
& feedback on my performance. \\
& My supervisor deals effectively with poor \\
& performance. \\
& My supervisor treats me with respect. \\
& My supervisor recognizes me for doing \\
good work. & My supervisor considers my ideas. \\
My supervisor trusts me. & My supervisor has a clear view of where \\
our department is going and how to get & \\
& \\
&
\end{tabular}


Table 3 (cont.)

Variables Measured in Work Climate

Survey

Perceived work environment

\begin{tabular}{ll}
\hline Hygiene factor & \multicolumn{1}{c}{ Measure } \\
\hline I trust my co-workers. & I am consistently treated with respect by \\
& my co-workers. \\
& I can count on my co-workers to help out \\
& when needed. \\
& My co-workers and I work as part of a \\
& team. \\
& People care about each other in my \\
& unit/department. \\
& Someone in my unit/department cares \\
about me as a person. & When I joined my unit/department, I was \\
made to feel welcome. & Mith other workgroups or departments. \\
& \\
&
\end{tabular}

Good Relationships with Co-workers 
Table 3 (cont.)

Variables Measured in Work Climate

Survey

Perceived work environment

\begin{tabular}{ll}
\hline \multicolumn{1}{c}{ Hygiene factor } & Measure \\
\hline & Ignoring my unit/department's core \\
& values at work will get me in trouble. \\
& There is a clear and consistent set of values \\
& that governs the way we conduct our work. \\
Presence of Core Values & All units/departments of the institution \\
& share common values.
\end{tabular}


Table 3 (cont.)

Variables Measured in Work Climate

Survey

Perceived work environment

\begin{tabular}{ll}
\hline Hygiene factor & Measure \\
\hline & My salary/pay rate is competitive \\
& when compared to similar jobs at other \\
& organizations. \\
& I am fairly paid for the work I do. \\
& Salary/pay increases are appropriate. \\
& I understand how my base salary is \\
& determined. \\
& My salary/pay rate is a significant factor in \\
my decision to stay at the institution.
\end{tabular}

Satisfaction with Salary 
Table 3 (cont.)

Variables Measured in Work Climate

Survey

Perceived work environment

Hygiene factor

Measure

The institution's benefits package meets

my needs.

My costs associated with the benefits

plan (co-pays, deductibles, premiums) are

reasonable.

The benefits package is a significant factor

in my decision to stay at the institution.

The institution's benefits package has been adequately explained to me.

Satisfaction with Benefits 
Table 3 (cont.)

Variables Measured in Work Climate

Survey

Outcome of the work environment

Imagine your ideal job. My current

position compares favorably to my

ideal job.

I am satisfied with my job.

Consider all the expectations you had when

you started your current job. My job

exceeds these expectations.

Job Satisfaction 


\section{APPENDIX C}

Table 4

Demographic summary

\begin{tabular}{|c|c|c|c|c|c|c|c|}
\hline & $\mathrm{N}$ & Range & Minimum & Maximum & Mean & SE & $\mathrm{SD}$ \\
\hline Age & 315 & 9 & 1 & 10 & 5.62 & .135 & 2.397 \\
\hline Gender & 338 & 2 & 1 & 3 & 1.72 & .033 & .613 \\
\hline Length of & 313 & 7 & 1 & 8 & 3.83 & .129 & 2.282 \\
\hline \multicolumn{8}{|l|}{ Employment } \\
\hline Level of Education & 313 & 7 & 1 & 8 & 4.88 & .096 & 1.697 \\
\hline Minority Status & 290 & 2 & 1 & 3 & 1.91 & .020 & .337 \\
\hline Salary & 306 & 7 & 1 & 8 & 2.75 & .069 & 1.21 \\
\hline Area of Employment & 322 & 1 & 0 & 1 & .696 & .026 & .461 \\
\hline No. of Fulltime & 261 & 80 & 0 & 80 & 10.67 & .648 & 10.467 \\
\hline \multicolumn{8}{|l|}{ Professional Staff in } \\
\hline Department & & & & & & & \\
\hline
\end{tabular}


APPENDIX D

Table 5

$\begin{array}{ccc}\text { Cronbach's } & \text { Corrected } & \text { Cronbach's } \\ \text { Alpha } & \text { Item-Total } & \text { Alpha if } \\ & \text { Correlation } & \text { Item Deleted }\end{array}$

Factor: Clarity of Mission

.840

I understand how my work supports the institution's mission.

.510

.841

I understand how my work supports the mission of my unit/department.

.661

I know what is expected of me at work.

Work is organized so that each person can see the relationship between his/her job and the goals of the institution.

The goals of my unit/department are clear to me.

\section{Factor: Good Feelings About Organization}

I feel a strong sense of belonging to the institution.

I enjoy discussing the institution with people who do not work here.

I have a strong commitment to the institution.

I am proud to work for the institution.

I care about the future of the institution.

\section{Factor: Opportunities For} Advancement

Opportunities for advancement or promotion exist within the institution.

I know what is required of me to advance within the institution.

Internal candidates receive fair consideration for open positions. 
Table 5 (cont.)

$\begin{array}{ccc}\text { Cronbach's } & \text { Corrected } & \text { Cronbach's } \\ \text { Alpha } & \text { Item-Total } & \text { Alpha if } \\ & \text { Correlation } & \text { Item Deleted }\end{array}$

\section{Factor: Professional Growth Opportunities}

My unit/department offers the training or education that I need to grow in my job.

I have received the necessary training to do my job well.

I have had opportunities at work to learn and grow in the past year.

There is someone at work who encourages my development.

Someone has talked to me about my progress in the past year.

Factor: Recognition

Those whom I serve recognize my good work.

My contributions are valued by members of the institutional community outside of

my unit/department.

In the last seven days I have received recognition or praise for doing good work.

I get appropriate recognition when I have done something extraordinary.

Expressions of thanks and appreciation are common in my unit/department.

Factor: Responsibility

I have control over how I do my work.

My opinion counts at work.

I have a say in decisions that affect my work.

The physical environment allows me to do my job.

I have the necessary resources, tools, or equipment to do my job. 
Table 5 (cont.)

$\begin{array}{ccc}\text { Cronbach's } & \text { Corrected } & \text { Cronbach's } \\ \text { Alpha } & \text { Item-Total } & \text { Alpha if } \\ & \text { Correlation } & \text { Item Deleted }\end{array}$

Factor: Work Itself

.892

I enjoy the type of work I do.

.785

.854

My job is interesting.

.838

My job gives me a sense of accomplishment.

I make a difference in my unit/department.

.611

.914

\section{Factor: Effective Senior Management}

.954

Senior management keeps employees informed.

Senior management effectively

communicates the goals and strategies of our unit/department.

Senior management demonstrates leadership practices that are consistent with the stated values of our

$$
.938
$$
unit/department.

\section{Factor: Effective Supervisor}

My supervisor communicates well.

My supervisor manages people

effectively.

My supervisor is an effective decisionmaker.

Overall, I would give my supervisor high ratings.

My supervisor creates an environment that fosters trust.

My supervisor is approachable and easy to talk with. 
Table 5 (cont.)

$\begin{array}{ccc}\text { Cronbach's } & \text { Corrected } & \text { Cronbach's } \\ \text { Alpha } & \text { Item-Total } & \text { Alpha if } \\ & \text { Correlation } & \text { Item Deleted }\end{array}$

My supervisor gives me constructive feedback on my performance.

My supervisor deals effectively with poor performance.

.757

.975

My supervisor treats me with respect.

.856

.973

My supervisor recognizes me for doing good work.

.974

My supervisor considers my ideas.

.974

My supervisor trusts me.

.975

My supervisor has a clear view of where our department is going and how to get .806

.974

there.

Factor: Good Relationships with Coworkers

I trust my co-workers.

I am consistently treated with respect by my co-workers.

I can count on my co-workers to help out when needed.

My co-workers and I work as part of a team.

People care about each other in my unit/department.

Someone in my unit/department cares about me as a person.

When I joined my unit/department, I was made to feel welcome.

My workgroup collaborates effectively with other workgroups or departments.

Ignoring my unit/department's core values at work will get me in trouble.

There is a clear and consistent set of values that governs the way we conduct our work. 
Table 5 (cont.)

$\begin{array}{ccc}\text { Cronbach's } & \text { Corrected } & \text { Cronbach's } \\ \text { Alpha } & \text { Item-Total } & \text { Alpha if } \\ & \text { Correlation } & \text { Item Deleted }\end{array}$

All units/departments of the institution share common values.

\section{Factor: Salary Satisfaction}

My salary/pay rate is competitive when compared to similar jobs at other organizations.

I am paid fairly for the work I do.

Salary/pay increases are appropriate.

I understand how my base salary is determined.

My salary/pay rate is a significant factor in my decision to stay at the institution.

Factor: Benefits Satisfaction

The institution's benefits package meets my needs.

My costs associated with the benefits plan.

The benefits package is a significant factor in my decision to stay at the institution.

The institution's benefits package has been adequately explained to me.

\section{Factor: Job Satisfaction}

Imagine your ideal job. My current position compares favorably to my ideal job.

Consider all the expectations you had when you started your current job. My 


\section{APPENDIX E}

Table 6

Hierarchical regression model results

\begin{tabular}{|c|c|c|c|c|c|c|c|}
\hline & $R$ & $R^{2}$ & $\begin{array}{c}R^{2} \\
\text { Change } \\
\end{array}$ & $B$ & $S E B$ & $\beta$ & $t$ \\
\hline Step One & .190 & .036 & .036 & & & & \\
\hline Age & & & & -.050 & .037 & -.131 & -1.38 \\
\hline Gender & & & & .117 & .135 & .036 & .866 \\
\hline Length of Employment & & & & -.001 & .037 & -.003 & -.038 \\
\hline Level of Education & & & & .018 & .040 & .031 & .439 \\
\hline Minority status & & & & .008 & .194 & .003 & .043 \\
\hline Salary & & & & .160 & .062 & .205 & 2.56 \\
\hline Step Two & .199 & .040 & .004 & & & & \\
\hline Age & & & & -.048 & .037 & -.124 & -1.29 \\
\hline Gender & & & & .138 & .138 & .074 & 1.00 \\
\hline Length of Employment & & & & -.001 & .037 & -.002 & -.027 \\
\hline Level of Education & & & & .017 & .041 & .030 & .412 \\
\hline Minority status & & & & .005 & .194 & .002 & .027 \\
\hline Salary & & & & .160 & .068 & .205 & 2.357 \\
\hline Area of Employment & & & & .015 & .155 & .007 & .095 \\
\hline $\begin{array}{l}\text { Number of Fulltime } \\
\text { Professional Employees }\end{array}$ & & & & .005 & .006 & .061 & .863 \\
\hline
\end{tabular}


Table 6 (cont.)

Hierarchical regression

model results

\begin{tabular}{|c|c|c|c|c|c|c|c|}
\hline & $R$ & $R^{2}$ & $\begin{array}{c}R^{2} \\
\text { Change } \\
\end{array}$ & $B$ & $S E B$ & $\beta$ & $t$ \\
\hline Step Three & .827 & $.683 * * *$ & $.644 * * *$ & & & & \\
\hline Age & & & & -.006 & .022 & -.016 & -.272 \\
\hline Gender & & & & .060 & .081 & .032 & .731 \\
\hline Length of Employment & & & & .008 & .022 & .020 & .379 \\
\hline Level of Education & & & & -.035 & .0251 & -.062 & -1.430 \\
\hline Minority status & & & & -.134 & .115 & -.048 & -1.167 \\
\hline Salary & & & & .003 & .041 & .003 & .062 \\
\hline Area of Employment & & & & -.001 & .092 & -.001 & -.016 \\
\hline $\begin{array}{l}\text { Number of Fulltime } \\
\text { Professional Employees }\end{array}$ & & & & .002 & .004 & .018 & .414 \\
\hline Clarity of Mission & & & & .139 & .082 & .108 & 1.686 \\
\hline $\begin{array}{l}\text { Good Feelings about } \\
\text { Organization }\end{array}$ & & & & .072 & .055 & .070 & 1.313 \\
\hline $\begin{array}{l}\text { Opportunities for } \\
\text { Advancement }\end{array}$ & & & & .046 & .057 & .046 & .810 \\
\hline $\begin{array}{l}\text { Professional Growth } \\
\text { Opportunities }\end{array}$ & & & & .044 & .064 & .047 & .689 \\
\hline Recognition & & & & .202 & .059 & $.221 * *$ & 3.432 \\
\hline Responsibility & & & & .346 & .079 & $.315 * * *$ & 4.391 \\
\hline Work itself & & & & .302 & .068 & $.227 * * *$ & 4.422 \\
\hline
\end{tabular}

Note. Statistical significance: ${ }^{*} p<.05 ;{ }^{* *} p<.01 ;{ }^{* * *} p<.001$ 
Table 6 (cont.)

Hierarchical regression

model results

\begin{tabular}{|c|c|c|c|c|c|c|c|}
\hline & $R$ & $R^{2}$ & $\begin{array}{c}R^{2} \\
\text { Change }\end{array}$ & $B$ & $S E B$ & $\beta$ & $t$ \\
\hline Step Four & .839 & $.704 * * *$ & $.021 * * *$ & & & & \\
\hline Age & & & & -.001 & .022 & -.003 & -.055 \\
\hline Gender & & & & .096 & .081 & .052 & 1.184 \\
\hline Length of Employment & & & & .005 & .022 & .011 & .221 \\
\hline Level of Education & & & & -.049 & .025 & -.086 & -1.905 \\
\hline Minority status & & & & -.132 & .114 & -.047 & -1.155 \\
\hline Salary & & & & -.001 & .041 & -.001 & -.028 \\
\hline Area of Employment & & & & -.006 & .092 & -.003 & -.061 \\
\hline $\begin{array}{l}\text { Number of Fulltime } \\
\text { Professional Employees }\end{array}$ & & & & .002 & .004 & .026 & .590 \\
\hline Clarity of mission & & & & .129 & .086 & .100 & 1.493 \\
\hline $\begin{array}{l}\text { Good Feelings about } \\
\text { Organization }\end{array}$ & & & & .098 & .056 & .095 & 1.766 \\
\hline $\begin{array}{l}\text { Opportunities for } \\
\text { Advancement }\end{array}$ & & & & .053 & .060 & .053 & .879 \\
\hline $\begin{array}{l}\text { Professional Growth } \\
\text { Opportunities }\end{array}$ & & & & -.008 & .065 & -.008 & -.119 \\
\hline Recognition & & & & .139 & .061 & $.152 *$ & 2.270 \\
\hline Responsibility & & & & .296 & .082 & $.270 * * *$ & 3.599 \\
\hline Work itself & & & & .303 & .069 & $.228 * * *$ & 4.390 \\
\hline $\begin{array}{l}\text { Effective Senior } \\
\text { Management }\end{array}$ & & & & .026 & .050 & .034 & .516 \\
\hline Effective Supervisor & & & & .183 & .064 & $.211 * *$ & 2.872 \\
\hline $\begin{array}{l}\text { Good Relationships with } \\
\text { Co-workers }\end{array}$ & & & & .045 & .070 & .036 & .651 \\
\hline Presence of Core Values & & & & -.134 & .063 & $-.126 *$ & -2.116 \\
\hline Satisfaction with Salary & & & & .005 & .053 & .006 & .099 \\
\hline $\begin{array}{l}\text { Satisfaction with } \\
\text { Benefits }\end{array}$ & & & & -.007 & .049 & -.007 & -.145 \\
\hline
\end{tabular}

Note. Statistical significance: ${ }^{*} p<.05 ; * * p<.01 ; * * * p<.001$ 


\section{Table 7}

\section{APPENDIX F}

\section{Correlations}

\begin{tabular}{|c|c|c|c|c|c|c|c|c|c|c|}
\hline & 1 & 2 & 3 & 4 & 5 & 6 & 7 & 8 & 9 & 10 \\
\hline $\begin{array}{l}\text { 1. Job Satisfaction } \\
\text { 2. Job category: }\end{array}$ & 1.000 & -.050 & .077 & .000 & -.077 & .021 & -.042 & .113 & .058 & .642 \\
\hline $\begin{array}{l}\text { Adminstration/Ex } \\
\text { empt Professional } \\
\text { Staff }\end{array}$ & -.050 & 1.000 & -.211 & .198 & -.172 & .126 & -.094 & -.094 & -.099 & -.028 \\
\hline $\begin{array}{l}\text { 3. Number of full- } \\
\text { time staff in } \\
\text { department }\end{array}$ & .077 & -.211 & 1.000 & -.172 & -.128 & .034 & -.093 & .014 & .047 & .160 \\
\hline 4. Gender & .000 & .198 & -.172 & 1.000 & -.043 & .035 & -.041 & -.276 & -.035 & -.061 \\
\hline 5. Age & -.077 & -.172 & -.128 & -.043 & 1.000 & -.100 & .620 & .424 & -.255 & -.069 \\
\hline 6. Minority Status & .021 & .126 & .034 & .035 & -.100 & 1.000 & -.044 & -.082 & -.057 & .044 \\
\hline $\begin{array}{l}\text { 7. Length of } \\
\text { Employment }\end{array}$ & -.042 & -.094 & -.093 & -.041 & .620 & -.044 & 1.000 & .263 & -.176 & -.050 \\
\hline 8. Salary & .113 & -.094 & .014 & -.276 & .424 & -.082 & .263 & 1.000 & -.032 & .105 \\
\hline $\begin{array}{l}\text { 9. Level of } \\
\text { Education }\end{array}$ & .058 & -.099 & .047 & -.035 & -.255 & -.057 & -.176 & -.032 & 1.000 & .053 \\
\hline $\begin{array}{l}\text { 10. Clarity of } \\
\text { Mission }\end{array}$ & .642 & -.028 & .160 & -.061 & -.069 & .044 & -.050 & .105 & .053 & 1.000 \\
\hline $\begin{array}{l}\text { 11. Good Feelings } \\
\text { about } \\
\text { Organization }\end{array}$ & .541 & -.124 & .068 & -.065 & .078 & .028 & .060 & .158 & .147 & .563 \\
\hline $\begin{array}{l}\text { 12. Opportunities } \\
\text { for Advancement } \\
\text { 13. Professional }\end{array}$ & .568 & .113 & .116 & .023 & .023 & .067 & .003 & .115 & .087 & .585 \\
\hline $\begin{array}{l}\text { Growth } \\
\text { Opportunities }\end{array}$ & .652 & .021 & .043 & -.020 & -.123 & .051 & -.101 & .080 & .137 & .661 \\
\hline 14. Recognition & .684 & .087 & -.023 & .016 & -.119 & .055 & -.148 & .051 & .132 & .578 \\
\hline 15. Responsibility & .745 & .024 & .029 & .016 & -.125 & .013 & -.102 & .127 & .099 & .688 \\
\hline $\begin{array}{l}\text { 16. Work Itself } \\
\text { 17. Effective }\end{array}$ & .590 & -.062 & .149 & -.106 & -.042 & .108 & .028 & .117 & .152 & .439 \\
\hline $\begin{array}{l}\text { Senior } \\
\text { Management }\end{array}$ & .590 & .074 & .111 & -.050 & -.157 & -.004 & -.179 & -.016 & .025 & .600 \\
\hline $\begin{array}{l}\text { 18. Effective } \\
\text { Supervisor }\end{array}$ & .673 & .049 & .010 & -.045 & -.148 & -.017 & -.126 & .030 & .108 & .622 \\
\hline $\begin{array}{l}\text { 19. Coworker } \\
\text { Relationships }\end{array}$ & .546 & -.013 & -.041 & -.027 & -.085 & .022 & -.023 & .095 & .128 & .517 \\
\hline 20. Core Values & .462 & .054 & .044 & .032 & -.087 & -.020 & -.123 & -.061 & -.127 & .604 \\
\hline $\begin{array}{l}\text { 21. Satisfaction } \\
\text { with Salary }\end{array}$ & .493 & .102 & -.087 & -.025 & .050 & -.039 & -.085 & .227 & .058 & .454 \\
\hline $\begin{array}{l}\text { 22. Satisfaction } \\
\text { with Benefits }\end{array}$ & .250 & .016 & .029 & -.078 & .045 & .041 & -.005 & .088 & .040 & .369 \\
\hline
\end{tabular}


Table 7 (cont.)

Correlations

\begin{tabular}{|c|c|c|c|c|c|c|c|c|c|c|c|c|}
\hline & 11 & 12 & 13 & 14 & 15 & 16 & 17 & 18 & 19 & 20 & 21 & 22 \\
\hline $\begin{array}{l}\text { 1. Job Satisfaction } \\
\text { 2. Job category: }\end{array}$ & .541 & .568 & .652 & .684 & .745 & .590 & .590 & .673 & .546 & .462 & .493 & .250 \\
\hline $\begin{array}{l}\text { Adminstration/Ex } \\
\text { empt Professional } \\
\text { Staff }\end{array}$ &.- & . 113 & .021 & .087 & .024 & $\begin{array}{c}- \\
.062\end{array}$ & .074 & .049 & $\overline{-} .013$ & .054 & .102 & .016 \\
\hline $\begin{array}{l}\text { 3. Number of full- } \\
\text { time staff in } \\
\text { department }\end{array}$ & .068 & .116 & .043 &.$\overline{-} .023$ & .029 & .149 & .111 & .010 & $\overline{-} .041$ & .044 & $\begin{array}{c}- \\
.087\end{array}$ & .029 \\
\hline 4. Gender & $\begin{array}{c}- \\
.065\end{array}$ & .023 & $\begin{array}{c}- \\
.020\end{array}$ & .016 & .016 & $\begin{array}{c}- \\
.106\end{array}$ & $\begin{array}{c}- \\
.050\end{array}$ & $\begin{array}{c}- \\
.045\end{array}$ & $\begin{array}{c}- \\
.027\end{array}$ & .032 & 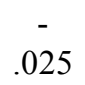 & $\begin{array}{c}- \\
.078\end{array}$ \\
\hline 5. Age & .078 & .023 & .123 & $\begin{array}{c}- \\
.119\end{array}$ & $\overline{-}-\overline{125}$ & .042 & $\begin{array}{c}- \\
.157\end{array}$ & - & $\begin{array}{c}- \\
.085\end{array}$ & $\begin{array}{c}- \\
.087\end{array}$ & .050 & .045 \\
\hline 6. Minority Status & .028 & .067 & .051 & .055 & .013 & .108 &. &. & .022 & $\begin{array}{c}- \\
.020\end{array}$ &. & .041 \\
\hline $\begin{array}{l}\text { 7. Length of } \\
\text { Employment }\end{array}$ & .060 & .003 & $\overline{-}$ & $\begin{array}{c}- \\
.148\end{array}$ & $\begin{array}{c}- \\
.102\end{array}$ & .028 & $\begin{array}{c}- \\
.179\end{array}$ &.$\overline{126}$ & .023 &.- & $\begin{array}{c}- \\
.085\end{array}$ & .005 \\
\hline 8. Salary & .158 & .115 & .080 & .051 & .127 & .117 & $\begin{array}{c}- \\
.016\end{array}$ & . 030 & .095 & $\begin{array}{c}- \\
.061\end{array}$ & .227 & .088 \\
\hline $\begin{array}{l}\text { 9. Level of } \\
\text { Education }\end{array}$ & .147 & .087 & .137 & .132 & .099 & .152 & .025 & .108 & .128 & .127 & .058 & .040 \\
\hline $\begin{array}{l}\text { 10. Clarity of } \\
\text { Mission }\end{array}$ & .563 & .585 & .661 & .578 & .688 & .439 & .600 & .622 & .517 & .604 & .454 & .369 \\
\hline $\begin{array}{l}\text { 11. Good Feelings } \\
\text { about } \\
\text { Organization }\end{array}$ & 1.00 & .468 & .463 & .520 & .511 & .440 & .433 & .429 & .400 & .454 & .333 & .217 \\
\hline $\begin{array}{l}\text { 12. Opportunities } \\
\text { for Advancement } \\
\text { 13. Professional }\end{array}$ & .468 & 1.00 & .573 & .613 & .537 & .411 & .564 & .474 & .383 & .423 & .559 & .326 \\
\hline $\begin{array}{l}\text { Growth } \\
\text { Opportunities }\end{array}$ & .463 & .573 & 1.00 & .644 & .728 & .509 & .584 & .673 & .572 & .487 & .539 & .350 \\
\hline 14. Recognition & .520 & .613 & .644 & 1.00 & .687 & .483 & .625 & .657 & .537 & .468 & .524 & .221 \\
\hline 15. Responsibility & .511 & .537 & .728 & .687 & 1.00 & .469 & .610 & .714 & .603 & .564 & .535 & .342 \\
\hline 16. Work Itself & .440 & .411 & .509 & .483 & .469 & 1.00 & .340 & .390 & .472 & .294 & .291 & .178 \\
\hline
\end{tabular}


Table 7 (cont.)

Correlations

\begin{tabular}{lccccccccccccc}
\hline & 11 & 12 & 13 & 14 & 15 & 16 & 17 & 18 & 19 & 20 & 21 & 22 \\
$\begin{array}{l}\text { 17. Effective } \\
\text { Senior }\end{array}$ & .433 & .564 & .584 & .625 & .610 & .340 & 1.00 & .707 & .420 & .592 & .482 & .297 \\
$\begin{array}{l}\text { Management } \\
\begin{array}{l}\text { 18. Effective } \\
\text { Supervisor }\end{array}\end{array}$ & .429 & .474 & .673 & .657 & .714 & .390 & .707 & 1.00 & .543 & .583 & .520 & .263 \\
$\begin{array}{l}\text { 19. Coworker } \\
\text { Relationships }\end{array}$ & .400 & .383 & .572 & .537 & .603 & .472 & .420 & .543 & 1.00 & .468 & .405 & .266 \\
$\begin{array}{l}\text { 20. Core } \\
\text { Values }\end{array}$ & .454 & .423 & .487 & .468 & .564 & .294 & .592 & .583 & .468 & 1.00 & .369 & .267 \\
$\begin{array}{l}\text { 21. Satisfaction } \\
\text { with Salary }\end{array}$ & .333 & .559 & .539 & .524 & .535 & .291 & .482 & .520 & .405 & .369 & 1.00 & .421 \\
$\begin{array}{l}\text { 22. Satisfaction } \\
\text { with Benefits }\end{array}$ & .217 & .326 & .350 & .221 & .342 & .178 & .297 & .263 & .266 & .267 & .421 & 1.00
\end{tabular}




\section{CURRICULUM VITAE}

NAME:

ADDRESS:

DOB:

EDUCATION

\& TRAINING:
J. Patrick Noltemeyer

147 Saint Mildreds Court

Danville, KY 40422

Louisville, Kentucky - September 22, 1979

B.S., Psychology

Centre College

1997-2001

M.S., Education

University of Kentucky

2001-2004

Ph.D., Education

University of Louisville

2008-2014

\section{WORK EXPERIENCE}

Centre College

Special Assistant to the President for

Institutional Research and Special Events

May 2013 - Present

Associate Dean

Director of Community Service and

The Bonner Scholars Program

August 2008 - May 2013

Director of Volunteer Service and

Bonner Program Coordinator

July 2005 - August 2007 
Director of Greek Life

July 2003 - July 2005

Georgetown College

Graduate Assistant for Student Life

Resident Director - Pi Kappa Alpha Fraternity

August 2002 - June 2003

University of Kentucky

Hall Director - Holmes Hall

August 2001 - June 2002

Governor's Scholars Program

Director of Scholars

Summers 2000-2007

Assistant Director of Scholars

Summers 1998-1999

Resident Advisor

Summer 1999

Professional Associations

AIR - Association for Institutional Research

NASPA - Student Affairs Administrators in Higher Education

ACPA - College Educators International

CPAK - College Personnel Association of Kentucky

AFA - Association of Fraternity Advisors 